\title{
Enugu in Technicolor
}

\section{Independent Production in Late-Colonial Nigeria}

"The index of economic independence will be measured not by pretentious economic plans or the amount of foreign capital that is attracted, but rather by the pursuit of calculated economic development programs based upon a definable economic doctrine that reflects the needs of the people."

-F. OLADIPO ONIPEDE, "AFRICAN NATIONALISM: A CRITICAL REPORT," 1956

"An offshoot of the surge of nationalism and general improvement in living and educational standards in West Africa is a desire for the development of a local film industry. As a matter of fact, East Nigeria has already completed plans which it hopes will make Enugu, its capital, the 'Hollywood of West Africa."

- HY HOLLINGER, “WEST AFRICA, UNDER NEW NATIONALISM, AIMS FOR OWN FILM INDUSTRY IN NIGERIA," VARIETY, JUNE 12, 1957

"It is one thing for the gentlemen of the West to disavow colonialism and declare it dead; it is quite another thing for them to abandon the habits of colonial masters."

-W. AlphaEUS HUNTON, DECISION IN AFRICA, 1957

"I support the right of sovereign nations to offer enticements to producers."

-JACK VAlENTi, QUOTED In THE GAZETTE (MONTREAL, CANAdA), FEBRUARY 8, 2002

On the eve of Nigerian independence, an American businessman named Lloyd Young traveled to Enugu, the administrative capital of the country's Eastern Region, in order to establish and nurture a film industry there-or so he and his cheerleaders (including the US Departments of State and Commerce) claimed. By 1957, having spent close to two years in Nigeria, and amid much talk of the country's promise as a "film capital", Young had succeeded only in producing a single feature-length motion picture for his own independent company, Lloyd Young \& Associates. That film-the melodrama The 


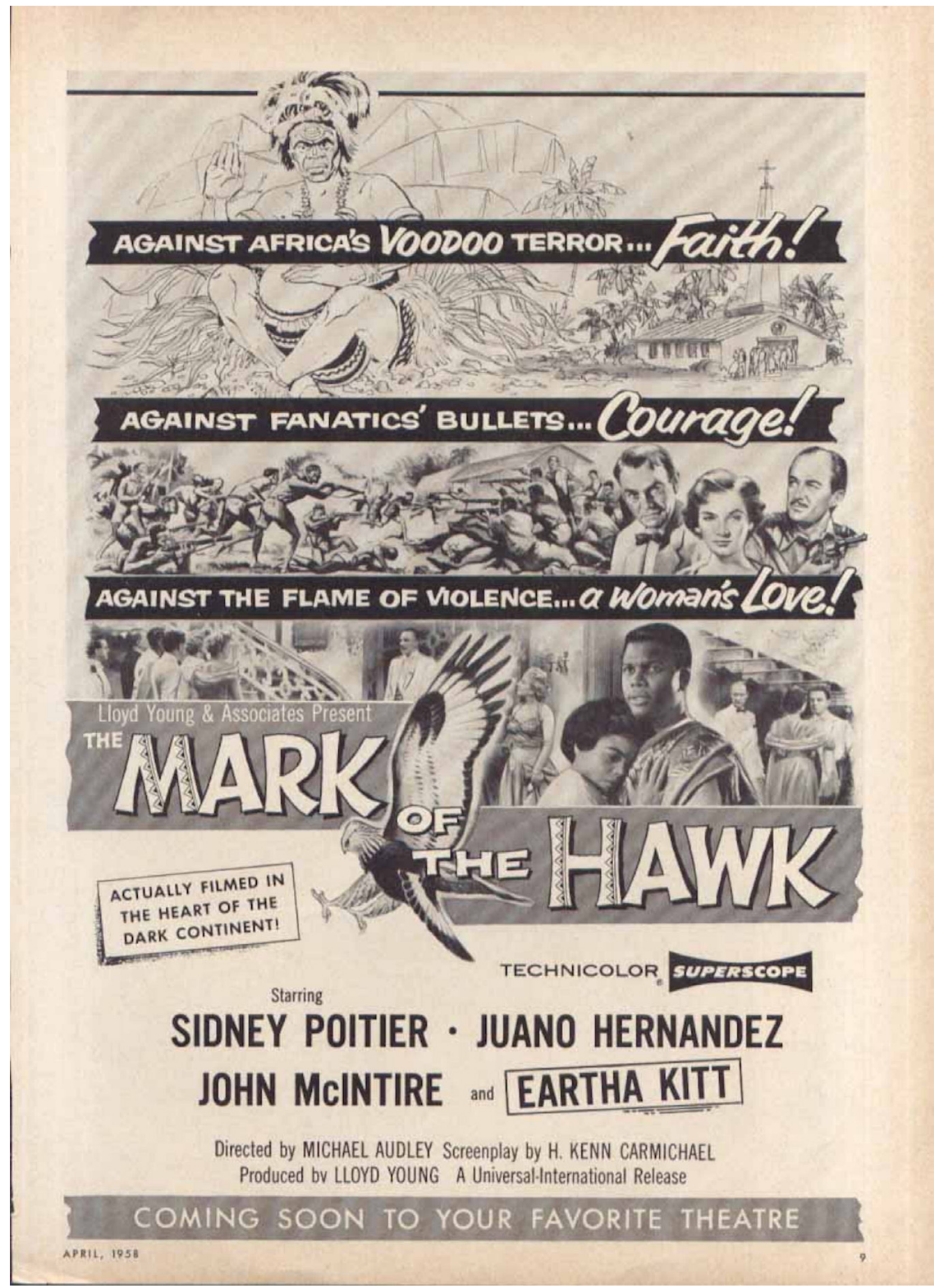

FIGURE 15. "ACTUALLY FILMED IN THE HEART OF THE DARK CONTINENT!": advertisement for The Mark of the Hawk.

Mark of the Hawk (Michael Audley, 1957)—is itself a telling document of decolonization as defined by and in the interests of American capital. It is, simply put, an advertisement for capitalist anticolonialism, a contradiction in terms whose very contrariety would be 
borne out by Young and his fellow market liberals, all of them openly enamored of free enterprise while happily and heavily relying on American and Nigerian state support.

The film's specific conditions of production-the precise political-economic circumstances that made it possible-are equally instructive, suggesting as they do the extent to which Enugu, as the seat of a regional government seeking fiscal autonomy in the waning days of colonial rule, was pressured to pursue a species of mixed economy that would ultimately benefit only an ensemble of American interlopers. These included the Board of Foreign Missions of the Presbyterian Church; the Methodist Church of America; Film Productions International, an independent company established in Burbank in 1955 and oriented toward the religious market, making films for, among other organizations, the Commission on Missionary Education; and Lloyd Young, for whose fledgling company The Mark of the Hawk served as an "exotic" calling card. ${ }^{1}$ Funding for the film was hardly limited to the aforementioned religious groups, all of which were eager to enter the business of film production at a time, in the immediate aftermath of the (partial and temporary) breakup of vertical integration in Hollywood, when alternatives to studio financing were proliferating in response to a perceived power vacuum. It also came, crucially, from Enugu, which supported the making of The Mark of the Hawk in exchange for gains that never materialized.

A curious chapter in the history of foreign capital's efforts to shape the landscape of screen media in Nigeria, the story of Young in Enugu is that of a public-private partnership premised on the need to "develop" decolonizing Nigeria along firmly capitalist lines, one that vividly evokes Antonio Gramsci's sense of hegemony as involving more than the simple dominance of the periphery by the center. In Gramscian terms, hegemony is a process, one that requires the active (if coerced) participation of the periphery in the mechanisms of its own domination, such that the economic capabilities of the emergent, outlying state are harnessed to the hegemon's interests. In this process, Robert Cox makes clear in his influential work on the "internationalizing" of the state, capitalist "values and understandings are relatively stable and unquestioned"; they "appear to most actors," states and nonstate entities alike, "as the natural order."2 Fittingly, The Mark of the Hawk is explicitly about such acquiescence, such normalization. It directly addresses the need for decolonizing countries to capitulate to capitalism-to accede to its specific, globalizing demands-lest they be "swallowed up" by the "Communist menace."3

Anticommunism was a convenient pretext for capitalist expansion, and it was often recognized as such by African intellectuals. In an address delivered at the Plenary Session of the British Peace Congress in London in 1949, Nnamdi Azikiwe, who would serve as Premier of the Eastern Region during the production of The Mark of the Hawk, noted, "Now the peoples of Africa are being told that it is necessary, in the interest of peace and the preservation of Christianity, that they should be ready to fight the Soviet Union, which the war buglers allege is aiming at world domination." In the film, capitalist goals are at once general and firmly focused on 
the mining of natural resources-an industrial practice that, the film argues, need not be carried out under the oversight of colonial masters, but that may in fact be expanded by "native decision" to include the work of foreign corporations, whose payment of rents will profitably replace (and stand as the principled antithesis of) the colonial collection of taxes.

The Mark of the Hawk should thus be seen as a cinematic extension of state efforts that dated at least to the CIA's confidential report The Break-Up of the Colonial Empires and Its Implications for US Security (1948), which paid particular attention to resource-rich Nigeria and fretted over the country's susceptibility to Soviet propaganda. ${ }^{5}$ An important source of tin and other raw materials, Nigeria was also the site of what the CIA, in something of a misnomer, dubbed "the Zik movement" - an expression of "rising nationalism" that directly threatened US military and economic security. According to the CIA, Zikist agitation was, because opposed to colonial power, likely to lead directly to resentment of US economic dominance (understood in the report as an achievement of World War II that was sure to extend into the postcolonial epoch). The Zikist movement's specifically "Negro" character posed an additional challenge, of course. Black economic nationalism was doubly daunting for a neocolonial enterprise that, the CIA freely admitted, was insufficiently antiracist. "Capturing the 'good will' of nations achieving their independence was vital," notes David H. Price, "and a failure to do so would result in antagonism toward the United States and a loss of vital clients." The task of securing postcolonial loyalties, pursued well in advance of political independence, assumed diverse forms in relation to Nigeria. Certainly "foreign aid and promises of technical assistance and modernization" were materially and rhetorically effective, but equally crucial were cinematic reflections on decolonization. ${ }^{6}$ Film, too, was expected to temper demands for economic nationalism, helping to balance US and postcolonial African interests in a world in which European power was on the decline.

Cinema's mystifying potential-its capacity to overwhelm the senses, manipulate the emotions, and generally deflect from the very political economy that made it possible and, for American agents, profitable-was indispensable. A growing number of filmmakers, supported by public and private foundations, government agencies, and major corporations, endeavored to represent the purported distance between the United States and its European allies. In its own way, The Mark of the Hawk reflects the Eisenhower administration's staunch determination "that the United States not appear associated, even indirectly, with sponsoring what seemed a return to the era of colonial domination."' Indeed, Eisenhower himself championed the film both for its specific textual elements and for the precise political economy-the particular "development program"-out of which it emerged. ${ }^{8}$ Like the broader construction of large-screen cinema in Nigeria, the making of The Mark of the Hawk in that country involved "technological infusions along with accompanying ideological overhauls." It also epitomized the limitations of 
modernization theory. Viewed from a postcolonial vantage, it vividly reveals how "the measurable outcomes for development often had little to do with improving the lot of underdeveloped nations per se." Indeed, "development aid" as disbursed in the 1950 ( and beyond) was merely "a weapon against communism, a tool to be used against insurgents." So was The Mark of the Hawk itself.

On those rare occasions when the film has been cited at all, The Mark of the Hawk has been subjected merely to aesthetic evaluation, and dismissed as, in the words of one critic, "an insignificant sermonette" - a condescending characterization whose very redundancy is emblematic of interpretive approaches that, through their hyperbolic derision, function to preclude attention to the political economy of moviemaking in pre-independence Enugu. ${ }^{10}$ For whatever its formal shortcomings, The Mark of the Hawk was produced in-and partly "for"-a regional government preparing for a new period in Nigerian history, a political watershed that promised to place the country on an economic par with Malaysia, Taiwan, and Thailand. This unprecedented epoch would require forms of cinematic self-representation that could be exported to the wider world, and employed as promotions for Nigeria's environmental splendor, cultural richness, and democratic progress.

This chapter challenges the assumption that The Mark of the Hawk signifies nothing more than artistic failure. It focuses on the film's broader significance in late-colonial Nigeria and contextualizes its plot and themes in relation to the growing number of Hollywood films that, shot on location outside of the United States (including in Africa south of the Sahara) reliably functioned as Cold War advertisements for American-style capitalism-instruments of "the propagation and extension of the American business system and its values."11 (In Capitalism and Freedom, first published in 1962, Milton Friedman would famously claim that "competitive capitalism" - by which Friedman meant "the organization of the bulk of economic activity through private enterprise operating in a free market" -is "a necessary condition for political freedom.") ${ }^{12}$ In taking The Mark of the Hawk seriously as an instrument of statecraft, I heed Reinhold Wagnleitner's call for scholars of film and media to "rise above judgments of aesthetic disdain" in order to address consequential questions of political economy. ${ }^{13}$ The entrenchment in and dependence on Enugu of Lloyd Young \& Associates also disproves Hyginus Ekwuazi's 1987 claim that "there has never been any foreign-owned film production company in Nigeria" - a claim that has been uncritically reproduced in scholarly as well as popular accounts. ${ }^{14}$ The excavation of this history thus has major historiographical implications. Taking seriously Enugu's status as an important administrative region in a modern bureaucratic state in the process of development, it is possible to better understand-to particularize-some of the mechanisms by which Hollywood interests became incorporated into Nigerian political and economic logics, even prior to independence.

In the 1950s, the Eastern Region boasted multiple open-air cinemas, including the Rex Cinema in Enugu and the Emy Cinema in Aba, located about ninety miles 
south of the seat of the regional government. The Rex was started by a Lebanese man named Elias Solomon, who came from a family with major cinema holdings throughout Nigeria. The smaller, indigenous-owned Emy, by contrast, often served as a site of political events-a place in which individuals could debate the nature of the Nigerian state in the lead-up to independence. A two-day economic conference was held there in May 1952. Politician Margaret Ekpo, a Nigerian women's rights activist and social mobilizer, hosted another meeting there in February 1953. ${ }^{15}$ Two years later, the nationalist A.A. Nwafor Orizu delivered his address "The Leadership We Want" at the Emy, while the Nigerian jurist Taslim Olawale Elias made use of the cinema for the first public reading of his paper "Towards Nationhood in Nigeria." ${ }^{16}$ Cinemas in the Eastern Region were, then, sites of political debate, including about the nature of cinema itself.

In the lead-up to and immediate aftermath of its attainment of self-government, the Eastern Region was a self-fashioned alternative to what Brendan Shehu would term "the extreme conservatism" of the federal government in the area of "film development."17 The evidently "inadequate appreciation of films as a source of profit" among local financial institutions and the local business community could be rectified, according to Enugu's emergent bureaucratic logic, by the regional government's commitment to attracting Hollywood capital-a commitment that would require considerable expenditure, as well as a willingness to "tempt" American filmmakers by promising tax breaks, climatically inviting shooting locations, and various forms of direct governmental assistance. ${ }^{18}$

"Most governments in the country do not think the film industry deserves any priority in terms of funding," Shehu would later complain. But the Enugu of the 1950s, openly eager to realize the cultural potential of the Igbo (one of the foundational promises of federalism), was committed to sponsoring cinema's regional development, albeit in a way that explicitly demanded the importation of American "expertise," and that, as a consequence, precluded sufficient attention to the cultivation of local talent. Hollywood was expected to perform such cultivation but plainly did not, however loudly the industry proclaimed its philanthropic motives in turning to Nigeria. ${ }^{19}$ Besides, as Shehu would put it, "mere copying of Western processes cannot engineer rapid changes," and with Hollywood all but abandoning Enugu after the completion of The Mark of the Hawk, the likelihood that a regional film industry would become a reality swiftly diminished until the Biafran Civil War appeared to obliterate it entirely. ${ }^{20}$ Enugu would, however, eventually realize these lofty ambitions-in a sense-through the prolific production of low-budget Nollywood films, and while the degree of regional governmental support for such films is eminently debatable, it is impossible to ignore Enugu's contemporary significance as a wellspring of popular media. ${ }^{21}$

The making of The Mark of the Hawk in mid-twentieth-century Enugu offers a vivid illustration of the postcolonial, particularly as defined by Robert J.C. Young as "a dialectical concept that marks the broad historical facts of decolonization 
and the determined achievement of sovereignty-but also the realities of nations and peoples emerging into a new imperialistic context of economic and sometimes political domination."22 The promise of decolonization, notes Abou B. Bamba in his study of Ivory Coast, "attracted many footloose historical actors, including development experts, social scientists, and foreign job-seekers anxious to tap into ... exceptional wealth."23 Lloyd Young was one such actor, eager to insert himself into United States-led development efforts in Nigeria, at a time when, as Bamba puts it, "the allure of American-inflected modernity loomed large." ${ }^{24}$ Young, then, was not simply a typical Hollywood independent; he was also a quintessential American modernizer, and it is not incidental that he ended up in Nigeria in the 1950 os.

Writing in 1956, the Africanist scholar Thomas Hodgkin remarked on the "growth of public spending" in Nigeria's Eastern Region, drawing attention to the precise political economy out of which Young's venture was, at that time, already growing. ${ }^{25}$ The Mark of the Hawk thus illuminates what Chika Okeke-Agulu has termed "the regionalization of the decolonization process." A self-conscious expression of Igbo practicality, Enugu's decision to finance the film was clearly "motivated by the desire for an effective platform for advancing a specifically regional cultural agenda." ${ }^{\text {"26 }}$ But the regional government's American collaborators-so necessary to its vision-had aims of their own. If British colonizers had previously endeavored to "organize and transform" Nigeria into a "fundamentally European construct," then Hollywood, via Lloyd Young \& Associates, sought to remake the countryor at least the Eastern Region-in distinctly American terms. ${ }^{27}$

That American capitalism could effectively remediate Nigeria, expiating the specifically economic sins of British colonialism, was not a novel argument in the 1950s. In the immediate aftermath of World War I, the Austrian political economist (and future American citizen) Joseph Schumpeter was already claiming that a "purely capitalist world can offer no fertile soil to imperialist impulses" - that "pure" capitalism, which Schumpeter associated with the United States, "is by nature anti-imperialist." ${ }^{28}$ In 1936, Grover Clark, an economist for the Carnegie Corporation of New York, published a detailed account of the economic irrationality of European colonialism, to which he implicitly proposed American capitalism as a solution. ${ }^{29}$ As Bamba puts it, "the global ascendancy of an Americansanctioned modernization paradigm necessarily involved passing judgment on colonial developmentalism." ${ }^{30}$ It is no accident that the Carnegie Corporation was, along with the Ford Foundation, among those championing the efforts of Lloyd Young \& Associates in the Eastern Region. The making of The Mark of the Hawk thus illustrates Hollywood's active participation in the politics of postcolonial development. The film was itself intended to promote American-influenced modernization, with a plot that pivots around "the moral saga orchestrated by the emergence of the American Century." "F1 "For many," writes Irene Gendzier, "Development and Modernization are terms that refer to a politics of reform designed 
to preserve the status quo while promising to alter it." ${ }^{32}$ There can be no better description of a film that was produced in neocolonial fashion as a critique of European colonialism.

The "economic possibilities" of Nigerian cinema, eagerly identified by the Eastern Region government in the 1950s, were ultimately immaterial to Lloyd Young \& Associates. ${ }^{33}$ Drawn to Enugu by the promise of tax incentives, low labor costs, and otherwise amenable shooting locations, Hollywood was-despite its public rhetoric-hardly interested in returning any favors. ${ }^{34}$ Film exposed in Enugu was processed in London for later assembly in Los Angeles. Far from the developer of a regional film industry, then, Lloyd Young \& Associates simply entered a long line of firms that flee once the resources of a site no longer suit their needs. ${ }^{35}$ For its part, newly autonomous Enugu proved itself to be a singularly facilitative government, capable of enforcing agreements that benefitted Hollywood capital. ${ }^{36}$ In this instance as in so many others, Hollywood's gain in overseas experience was, without a doubt, Nigeria's loss.

\section{ENUGU'S “EXTRAVERSION”}

The Mark of the Hawk depicts an African revolution that is ultimately suppressed, its passions redirected by an American missionary (played by John McIntire) who proposes that nation building proceed "within the framework of the Christian church." He prescribes "patient faith" in place of violent revolt, and his Christian paternalism puts an end to an anticolonial uprising that, in his view, is "moving too fast." Though made in Nigeria and eventually acquired by Universal-International for distribution to the country (as well as to Europe and the United States, among other global markets), The Mark of the Hawk is set in an unnamed British colony "somewhere in Africa." It therefore strategically subsumes a Nigerian specificity (which nevertheless remains eminently recognizable in, among other elements, the film's many exteriors) under an abstracted Africanity. ${ }^{37}$ It would, however, be a mistake to attribute such vagueness to racism alone. When The Mark of the Hawk was made, the "most basic foreign policy" of the MPAA "was to avoid giving offence to any country which provided the [Hollywood] industry with any revenue," however meager. ${ }^{38}$ With the MPAA advising Lloyd Young on his statesupported, quasi-diplomatic excursion into Nigeria, the producer-screenwriter well understood that he would not be able to explicitly identify Nigeria at the level of the film's narrative. ${ }^{39}$

This unwillingness to offend was a measure not simply of Nigeria's status as a potential source of box-office revenue but also of Britain's well-established importance as a foreign market for Hollywood films. If Universal, the film's distributor, was eager to bestow The Mark of the Hawk upon Nigerian cinemas (partly on the assumption that Nigerian audiences would want to see their own homeland on the screen), it was also committed to reaching the British domestic market, in 
which it regularly conducted business. ${ }^{40}$ Explicitly identifying Nigeria was thus out of the question for a "political" production that, though made at the tail end of formal imperial rule and in the wake of Ghana's independence, could not risk offending either a colonial government (which, in 1957, could easily have prevented the film's exhibition in Nigeria) or its counterpart in the metropole.

In The Mark of the Hawk, the African characters are said to "speak African." A workers' revolt, however evocative of actual Nigerian labor movements, is carefully tailored to reflect the sort of generalized anticolonial sentiments seen in the exactly contemporaneous Harry Belafonte film Island in the Sun (Robert Rossen, 1957). Set on the fictional island of Santa Marta ("just Jamaica with the name changed," Belafonte called it), the film's plot pivots around the efforts of "colored natives" to claim capitalism - formerly the exclusive preserve of white plantation owners-for themselves. ${ }^{41}$ While the film's premise was heavily indebted to the labor rebellions that had been convulsing the British West Indies since the 1930s, the finished work offers no such acknowledgment. Furthermore, as a Darryl F. Zanuck production, shot in CinemaScope in Barbados and Grenada, and distributed by Twentieth Century-Fox, Island in the Sun, like The Mark of the Hawk, suggests a continuation of imperial propaganda, with its persistent conviction "that Africans [and individuals of African descent] can do nothing except under tutelage"-least of all represent themselves in the struggle for emancipation. ${ }^{42}$ Jamaica could scarcely be directly referenced in a film about the "management" of Black liberation.

Such indirection had its costs in the case of The Mark of the Hawk: the reviewer for Film Bulletin, for instance, assumed that the melodrama was really about the Mau Mau uprising in Kenya, writing, “This Universal offering squarely tackles the problem of the Mau Mau in Africa. .. . The Lloyd Young production [has] some ticket-selling points in its favor; there are, indeed, some stunning Superscope on-location shots of primitive African splendor, handsomely done up in Technicolor." ${ }^{43}$ Universal's public description of the project, the first tagline that the studio prepared, was "Unrest and nationalism in Africa," which was later changed to the more attention-grabbing "Terror reigns as Africans seek equality!" 44 Vagueness of this sort was a product of persistent "British colonial sensitivities," even as the film in whose service it was so strategically employed was permitted to articulate US opposition to neo-mercantilist colonial policies.

The Mark of the Hawk thus became a cinematic enactment of what Ella Shohat and Robert Stam, using a filmic metaphor of their own, describe as "the historical lap-dissolve by which the British-dominated imperialism of the nineteenth century faded into the US-dominated imperialism of the twentieth." ${ }^{45}$ Throughout the 1950s, Hollywood was, as Brian Larkin puts it, a "visible symbol of a far-reaching transfer of economic and political dominance from Europe to the United States." ${ }^{46}$ Young, a Hollywood independent, had his own part to play in this process. Indeed, The Mark of the Hawk, as a Cold War advertisement for American capitalism, suggests some of the "very specific conditions in which traditional forms 
of colonialism were transformed into capitalist types of imperialism." It shows, in fact, how Enugu was made to emerge as one of many new "transmission belts for capitalist imperatives," all of them functioning to "enforce the 'laws' of the market." 47

Made by American independents committed to the ideal of free enterprise, its plot pivoting around the capitalist rejection of colonialist protectionism, The Mark of the Hawk vividly illustrates Edward Said's claim that Americans "tend to regard [themselves] as somehow exempt from the more sordid imperial adventures that preceded [their own]," even as they obviously exploit Africa and Africans. ${ }^{48}$ American cinema reliably served as a form of soft power, in contrast to, say, the British government's suppression of two daily papers-the West African Pilot and the Daily Comet-that, published in Lagos, had dared to cover local strike agitation. ${ }^{49}$ During the making of The Mark of the Hawk, American aid was placed in direct opposition to the Colonial Development Corporation (CDC). Of particular concern to Enugu's political elite was the latter's stagnating plans to provide "new and better houses" in the Eastern Region; by 1959, the CDC had succeeded only in approving Freetown Hotel in Sierra Leone, a project that, to many in Enugu, symbolized its commitment to European and American tourists. ${ }^{50}$

Evoking other anticommunist films of its era, The Mark of the Hawk features an extended flashback to an American clergyman's experiences in China, where this man of the cloth comes face to face with the "evils" of an "inhuman" communism. The regime, accusing him of being "an agent of American imperialism and white superiority," captures and imprisons him while he rather feebly insists that "God knows no color." When the clergyman, having escaped the clutches of the Chinese (whose communism is presented as a direct consequence of British imperial failure), returns to the African continent, it is to enjoin Africans to fasten themselves to the American cause of capitalism. Brokers of American-style modernization, the makers of The Mark of the Hawk lustily shared the goals of this particular character, strategically appealing to anticolonial nationalists as part of a global effort to curb perceived communist-led agitation.

Yet for all their contempt for British colonialism, these American filmmakers were working in a distinctly colonial vein. Albert Sarraut, the architect of the French colonial doctrine of mise en valeur, had long since promoted the idea that "economic development was essential to limit the popular appeal of leftist ideas to colonized peoples," to quote Martin Thomas. ${ }^{51}$ It is therefore no surprise that, as the Nigerian writer Godwin Udegbunem Meniru observed in 1954, American-Nigerian "cooperation"-the rhetorical production of cross-cultural "partnerships" like that between Hollywood and Enugu-was, despite the best efforts of Young and other American interlopers committed to "uplifting" Africans, "creating the impression of 'American Imperialism' in Africa." 52 For the more men like Young proclaimed their "faith in the ability of Americans to perfect and apply laws of progressive betterment and to uplift those lower on the evolutionary 


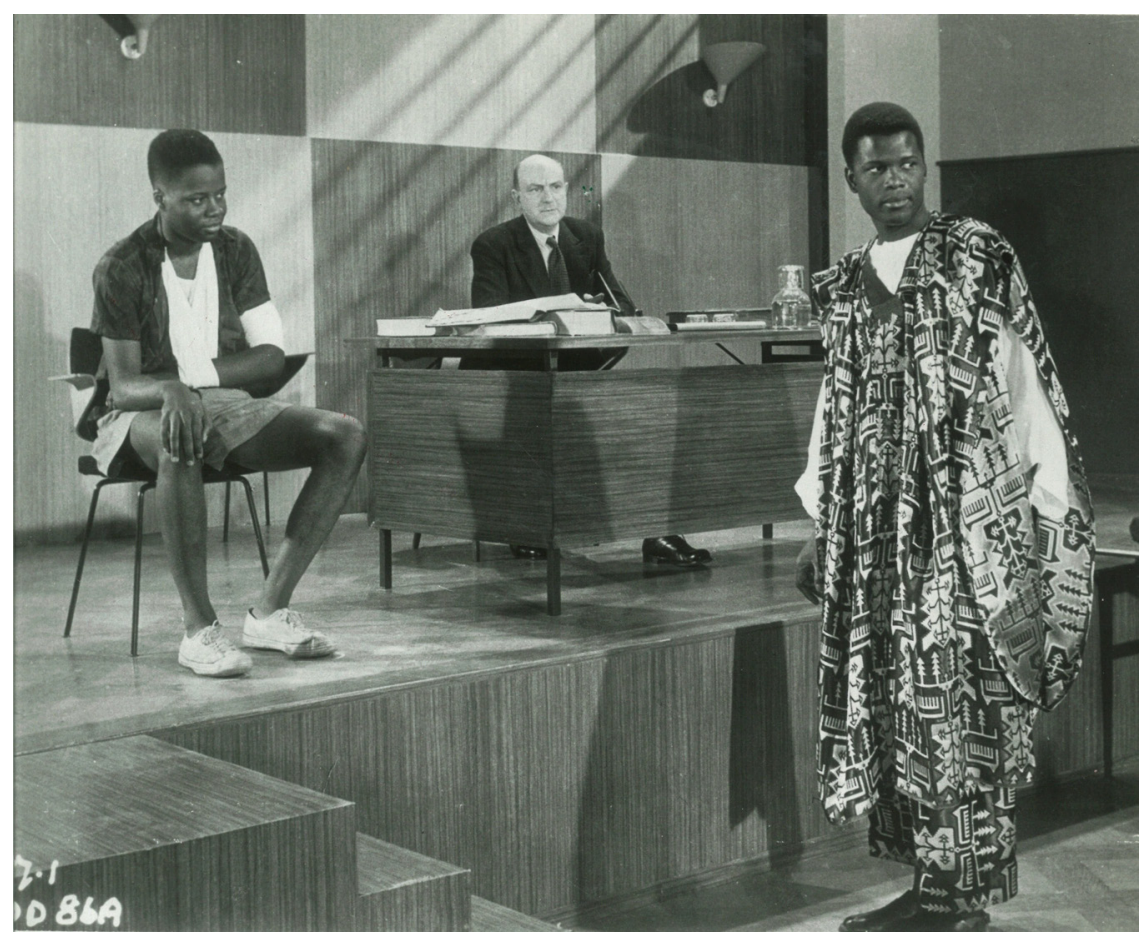

FIGURE 16. Debating the "timetable for independence" in The Mark of the Hawk.

scale," the more they seemed like agents of a new, Americanized mode of imperialism-exponents, that is, of America's global leadership position in the wake of the Second World War. ${ }^{53}$ However much "American freedoms" (particularly consumer freedoms) were discursively positioned as Nigeria's postcolonial bequest, the fact remained, for Meniru and other Nigerian intellectuals, that American exploitation of African resources was "hopelessly inimical to the freedom of Africa from European colonial imperialism." ${ }^{54}$ Young's production, pursued with "blessings and stacks of dollars from the Presbyterian Church" (as star Sidney Poitier put it), was also an effort to further Christianize the African continent-a cinematic means of "heralding Christianity as a vehicle for both spiritual and material development" in the postwar period..$^{55}$

From the very beginning, the effort was rife with ironies and paradoxes. The theme of Christian universalism was, first and foremost, very much in line with Hollywood's own precedents, including Frank Capra's The Bitter Tea of General Yen (1933), the first motion picture ever screened at New York's Radio City Music Hall. In that film, Barbara Stanwyck's American missionary, finding herself in Shanghai during the Chinese Civil War, attempts to serve a mediating function with her pious pronouncement "We're all of one flesh and blood!" For some Nigerians, 
living and working in Enugu a quarter of a century later, the Christian dimensions of The Mark of the Hawk could only echo memories (both direct and inherited) of the European missionaries whose excursions into the African continent had facilitated colonial conquest, lubricated imperial rule, and eroded local religions. ${ }^{56}$ Whether wittingly or not, the film's production represented the centennial of "the coming of the Gospel to Igboland," as Chinua Achebe called it, referring to the arrival in 1857 of the Church Missionary Society (CMS).$^{57}$ A branch of the Anglican Church, CMS established a mission at Onitsha in 1857. For Achebe, this curious centennial also augured Africa's "captur[ing] by Cold War manipulators" and "skew[ing] into a deadly season of ostensible ideological conflicts." ${ }^{58}$ Fittingly, then, The Mark of the Hawk was made to express, and advance, what was specifically "Christian" about anticommunism.

Enugu's accommodation of Hollywood's commercial-ideological ambitions should not, however, belie the fact that the Eastern Government clashed with the Church throughout this period. In 1956, for instance, the National Council of Nigeria and the Cameroons (NCNC) risked alienating Catholic leaders by adopting an educational policy designed to shift primary education away from the influence of the mission schools, which the government decried as "centers of dogmatic indoctrination." ${ }^{59}$ If Young was aware of these tensions, such cognizance is not evident in the finished film, which confidently cites a particular historical reality - the plain fact that Christian missionaries "did not contest the underlying structures of an economy in which Africans labored for a 'vigorous and enterprising [Euro-American] community."'60

In The Invention of Africa, V.Y. Mudimbe associates the work of Christian missionaries with the spread and normalization of capitalism, and that is precisely the discursive labor that The Mark of the Hawk performs. Its narrative bridges gaps between two towering figures in the African colonial experience-the "missionary who wanted to save souls and remake African culture in a 'Christian' mode and the owner of a mine or plantation who wanted to exploit labor without regard to the humanity of the worker." ${ }^{\prime 1}$ As Toyin Falola has pointed out, Christianization was introduced partly as a means of modernizing Nigeria's economy: "Conversion in the early years was motivated by a desire not just to preach the gospel but to redeem Africans from their so-called barbarism and economic deprivations; to create a so-called industrial class that would produce for the market; and to produce a new elite that would be the agents of change." ${ }^{2}$ The Mark of the Hawk was made toward the end of the period that witnessed Christianity's most dramatic expansion in southern Nigeria, a time when Nigerians were increasingly "expected not just to be good Christians but also 'civilized people' constituting a middle class with income." 63

The goal of "becoming moneyed" was seen by many activists as a distraction from-and distortion of - the decolonization struggle. As the Nigerian nationalist A.A. Nwafor Orizu put it in 1944, "What really disarmed Nigeria was the Christian 
missionary." ${ }^{64}$ For Orizu, Christianity and capitalism were two sides of the same imperialist coin, the former helping to naturalize the latter and, in the process, to prevent the possibility of meaningful political-economic change, as "the Christian missionary taught the gospel of turning the other cheek until every initiative toward repelling an enemy was lost." ${ }^{55}$ Orizu's denunciation of Nigeria's "'educated' class" - and of that class's capacity to "exploit the masses" by constantly reproducing an imported capitalist ideology_critically anticipated the roles of those elites in Enugu who, by the 1950s, firmly believed that "Hollywood knew best," and that the Eastern Region was right to accommodate Young and other American filmmakers capable of helping them realize their artistic and commercial ambitions. ${ }^{66}$

Enugu's "extraversion"-its attention to the world economy and commitment to assisting Hollywood filmmakers-was partly a product of the general process by which regional governments acquired public boards, including cinema corporations, in the lead-up to independence. ${ }^{67}$ In 1955, the Cinema Corporation of Nigeria, a government-owned body designed to give the Eastern Region an advantage by facilitating collaborations with foreign capital, was established. One of its first official actions was to invite the California-based Film Productions International to Enugu, where, working with Lloyd Young \& Associates, it began shooting The Mark of the Hawk in November $1956 .{ }^{68}$ Conceivably, Enugu's pronounced cinematic ambitions were compatible with the pursuit of "unity in diversity" by nationalist intellectuals, who "underscored the necessity of the stage of difference for the performance of the nation's unity." ${ }^{\text {" }}$

But Enugu's difference wasn't merely a matter of ethnicity; it was also, in the context of cinema, a measure of its specific willingness to collaborate with Hollywood capital in the name of regional progress. Enugu was plainly operating on the assumption that "American investors would assist in the development of native potentialities." ${ }^{70}$ The responsibilities of filmmaking in Enugu were effectively outsourced to Young's company at Young's behest. The grounds for this were that the Nigerian federal government, let alone the Eastern Region, was simply "unprepared" for a major cinematic undertaking, and that it had, despite the existence of the Eastern Region Film Unit (an offshoot of the Colonial Film Unit), no specialist knowledge-save Young's - on which it could possibly draw. ${ }^{71}$ Never mind that Lloyd Young \& Associates, a fledgling independent production company with no previous features to its name, was scarcely more "experienced" than the Cinema Corporation of Nigeria. Young was a representative of Hollywood in more than just a symbolic sense, his purpose to help pave the way for private (American) interests in Nigeria. These interests included, of course, the proliferation of independent producers of which he himself was a part.

On a promotional trip to New York in the spring of 1957, Young delivered a special "report on Nigeria's aspirations in the motion picture field." As a self-described "technical adviser and agent on film matters for the Nigerian government," Young was actively seeking American film technicians "willing to go to Nigeria on a 
three-year contract." He publicly confessed "that the Nigerian government realizes that the task will be a formidable one since it will have to organize a film industry from scratch," though his statement, which he offered as a means of encouraging American support, was not entirely accurate. ${ }^{72}$ By "Nigerian government," Young meant not the federal government but Enugu's regional one. Furthermore, the notion that any of Nigeria's administrative bodies would have to "organize a film industry from scratch" appeared to ignore the organizational, infrastructural, and artistic precedent of the Colonial Film Unit, which had spawned not only the Nigerian Film Unit but also, by the time Young arrived, the aforementioned Eastern Region Film Unit (based, like Young himself, in Enugu).$^{73}$ Indeed, Nigerians had begun formal training in film production nearly a decade earlier, in Accra in 1948, where a representative of Enugu, a sort of ambassador for the Eastern Region, worked under the instruction of experts, including a longtime employee of Kodak. Yet if these trainees had been taught, as one colonial student put it, "how to make films the English way," Young's tutelage, coming some ten years later, appeared to offer an alternative model emblematic of postwar Hollywood, with its runaway productions and increasingly desperate search for tax breaks and other benefits. ${ }^{74}$

For the most part, Africa meant a reduction in expenditure for Hollywood filmmakers who elected to work there, and who benefited-by design-from lower labor costs associated with the continent's histories of economic underdevelopment and enforced by the growing number of "political elites dedicated to the interests of capital investment."75 Young may have excluded Nigerians from abovethe-line positions on The Mark of the Hawk, but he took the opposite approach with respect to below-the-line labor, availing himself of Nigerian set builders, boom operators, gaffers, grips, and truck drivers. He thereby contradicted his own claim that Nigerians were entirely "unskilled" and "ignorant" in the context of cinema-a claim that becomes readable, in this context, as an elitist reduction of filmmaking to a strictly above-the-line affair. ${ }^{76}$

Meanwhile, with Young, an ambitious Enugu was placing its own cinematic development in the hands of an outsider, and an American, at that. This was hardly unusual at the time: Wolfgang Stolper, a German-born American economist, received Ford Foundation funding to draw up Nigeria's First National Economic Plan, which he completed with the cooperation not of a Nigerian expert but of another American, Lyle Hansen. ${ }^{77}$ Like Stolper, who would spend over eighteen months in Nigeria, Young established himself in the country for close to two years, where he played the part of modernizer-would-be developer of Enugu's filmproduction infrastructure-while doing little more than serving his own immediate interests and those of an expansionist American state.

Young's mission, the making of The Mark of the Hawk in an Enugu that was promised considerable assistance as it struggled to establish its own film industry, suggests a significant yet understudied augury of Stolper's plan, which would similarly favor "short-term benefit over long-term investment, free movement 
of capital, unhindered repatriation of profits by foreign corporations, and complete opposition to nationalization."78 Stolper's agenda- "at heart a neoliberal project that fetishized the market mechanism, profit maximization, and an export-oriented economy"-was the technocratic culmination of the logic that Young himself embodied, and that The Mark of the Hawk, as a film text, expresses. ${ }^{79}$ During the film's production, which took place between the fall of 1956 and the spring of 1957, the Rockefeller Brothers Fund set up its Lagos-based West Africa Program to provide technical assistance to men like Young-private US investors whom the program's director, Robert I. Fleming, would connect to various Nigerian government agencies, the goal being to locate sources of "soft money": subsidies, tax breaks, and other forms of government assistance. ${ }^{80}$ When the West Africa Program was terminated in June 1963, its functions were merely transferred to the Arthur D. Little Company, a Massachusetts-based international management consulting firm. ${ }^{81}$ In the spring of 1957 , the Rockefeller Brothers Fund sent John Camp, who was then in charge of the American International Association for Economic and Social Development (a philanthropic organization based in Caracas, Venezuela) to Enugu, where he met with Nnamdi Azikiwe and "visited a number of field projects including the very interesting 'community development' work" that involved (however misleadingly) the making of The Mark of the Hawk. Camp, for his part, was clearly less interested in this relatively small "cinema project" than in the need for "rural water supplies, access roads, and rural electrification." 2

In 1957, Azikiwe and other politicians consulted with Nelson Rockefeller and Stacy May, whose visit to Enugu coincided with Lloyd Young's stay there. ${ }^{83}$ The production of The Mark of the Hawk depended on the efforts of a number of intermediaries, among them the American consul, Ralph Hunt, and Jim McCullough, head of Mobil's West Africa operations, both of whom worked closely with Sir Ralph Gray, the Chief Secretary of the Federation, to ensure that outsiders like Young would be "received with the most open friendliness and cordiality." Enugu was to open its doors as well as its pocketbooks to them. (Camp wrote of the need to secure fiscal "contributions from the Eastern Region Government.") The goal was clear: accession to American capital would have to become second nature to Nigeria's political elites. ${ }^{84}$

But the film whose production these elites invited and assisted was intended as an advertisement not for true African autonomy but for the continent's ongoing dependence on American capital. Indeed, the sort of anticommunism embedded in (and expressed through the making of) The Mark of the Hawk "meant shying away from authentic social and economic planning, state ownership, and strong regulation of currency and capital flows." ${ }^{25}$ The Eastern Region's institution of a subsidy scheme, with tax-incentive packages for men like Young, was, according to the government, an attempt to turn Enugu into a major production center, but it is arguably best seen as an effort to "secure the field of play for corporate commerce and venture capital"- to, that is, "collapse ... the lines of separation 
between the state and the market" - amid the global rise of neoliberalism (which, Quinn Slobodian makes clear, was an intelligible ideology with abundant material effects long before the reigns of Reagan and Thatcher). ${ }^{86}$ The making of The Mark of the Hawk reveals, in fact, that Enugu was among the proliferating subnational contexts in which the "practical workings of neoliberalism have been tried and tested," to quote Jean Comaroff and John L. Comaroff. ${ }^{87}$

Installed in Enugu by the mid-1950s, Lloyd Young \& Associates-a foreign company-was treated as a "domestic" producer, and thus managed to benefit from Nigerian funding programs, despite pushback from Nigerian activists concerned about Hollywood's capacity to "swallow up" the entire Eastern Region. ${ }^{88}$ In a scathing article written during the production of The Mark of the Hawk, Oladipo Onipede condemned Nigeria's political elites for their unashamed, faux-naïve support for Hollywood's self-serving aims, and he praised the comparatively "dynamic response of India" to the ongoing production and increasingly aggressive exportation of "Hollywood's mythical Africa." He cited the decision of the Indian Central Board of Film Censors to ban eight films-West of Zanzibar (Tod Browning, 1928), The African Queen (John Huston, 1951), The Snows of Kilimanjaro (Henry King, 1952), Mogambo (John Ford, 1953), Below the Sahara (Armand Denis, 1953), Tanganyika (Andre deToth, 1954), African Adventure (Robert C. Ruark, 1954), and Untamed (Henry King, 1955) - in response to the complaints of African students at Delhi University. Onipede denounced the contrasting "silence and complacence" that, at the time, underwrote Hollywood's infiltration of the African continentprecisely the sort of complicity with Hollywood capital emblematized by Enugu's embrace of Lloyd Young \& Associates. ${ }^{89}$

As Onipede understood only too well, the American firm was expected to serve an educative purpose while in Enugu, representing "the transfer of industrial know-how from the United States to the rest of the world." ${ }^{90}$ Indeed, this was the purpose most frequently (if disingenuously) proclaimed by various Hollywood firms in their Nigerian operations throughout the 1950s and 1960s. Cinestar International, in attempting to "state as fully as possible the anticipated benefits to the economy of Nigeria" as it marketed its patented Multitrax language-conversion system, Cinego mobile-cinema packages, and plastic-and-nylon CineDome theaters, cited the "creation of new industry, [the] introduction of new technical processes, know-how, etc." as well as an expected "increase in employment of local labour."1 The case of The Mark of the Hawk, like that of Cinestar, is thus useful in contesting approaches to power as a zero-sum game in which private interests compete rather than collaborate with the state. After all, as Jan C. Jansen and Jürgen Osterhammel put it, "economic decolonization is a matter of degree," and The Mark of the Hawk was made possible by an elite network that straddled the stateprivate divide. ${ }^{2}$ Though buoyed by US private interests, the film was also financed by Enugu, which supported Young-via measures that O.U. Affiah, the Eastern Region's Minister of Customary Courts and Chieftaincy Affairs, maintained had 
been "introduced in the best interest of the people"-even at the risk of overextending the public sector and straining its fiscal capacity. ${ }^{93}$ Such support was hardly unprecedented, however. In 1950, the Nigerian government had instituted the allotment of semi-annual grants of $\$ 30,000$ for the purchase of American films, a program designed to fill the coffers of Hollywood studios producing the sort of audiovisual entertainment that Nigerians were said to favor. ${ }^{94}$ Enugu's contributions to Young's project did not derive from this source but rather from a regional budget, neither the first nor the last example of state monies being used to subsidize a Hollywood production..$^{95}$

In the 1950s, Enugu was so eager to recruit Hollywood investors that it engaged in various exchange programs intended to help cultivate the most conducive economic and social conditions for American capital. In 1954, Nnamdi Azikiwe, then Minister of Local Government and premier of the Eastern Region, joined the wealthy Nigerian businessman Louis P. Ojukwu on an "economic mission" to Europe and North America, where the two men acquired designs for "stimulating economic expansion" in soon-to-be-independent Nigeria. ${ }^{96}$ It is in this aspirational, cross-cultural context that Enugu's support for Lloyd Young and The Mark of the Hawk should be understood. One result of Azikiwe's trip was the Eastern Region Finance Corporation Law of 1954, which empowered a newly created statutory body (the Finance Corporation) to grant loans and subsidies, including to foreign firms like Lloyd Young \& Associates. ${ }^{97}$ Due to such concessions, Young's production would offer only marginal benefits to government revenue through the payment of direct taxes. ${ }^{98}$ (S.J. Timothy-Asobele would later complain of "the cutthroat entertainment tax being levied on [indigenous] film producers by the government" - precisely the sort of tax that was not imposed on the foreign makers of The Mark of the Hawk. $)^{99}$ Enugu certainly counted on benefitting indirectly through, say, the purchase by Young and his fellow Americans of highly taxed luxury goods thought to be attractive to tourists and other visitors, but there is little evidence to suggest that such purchases were actually made by those involved in the production of The Mark of the Hawk. ${ }^{100}$

However strenuously (and strategically) Young and others may have worked to distinguish American capitalism from British colonialism, the economic aims of the two systems were hardly incompatible by the late 1950s. The Mark of the Hawk makes no mention of this convergence, relying instead upon the rather tendentious notion that capitalist decolonization required Africans to align with a "uniquely" American program and to reject as retrograde any entreaties from their colonial masters as well as from the Soviet Union. The film emphasizes the inevitability of self-government-precisely what had brought Young to Nigeria in the first place. "I love Africa," declares one colonial administrator in the film. "We've given you a standard of living." In response, Poitier's character calls this an "incidental benefit," one that must not distract from the need to obtain a firm "timetable for independence." 


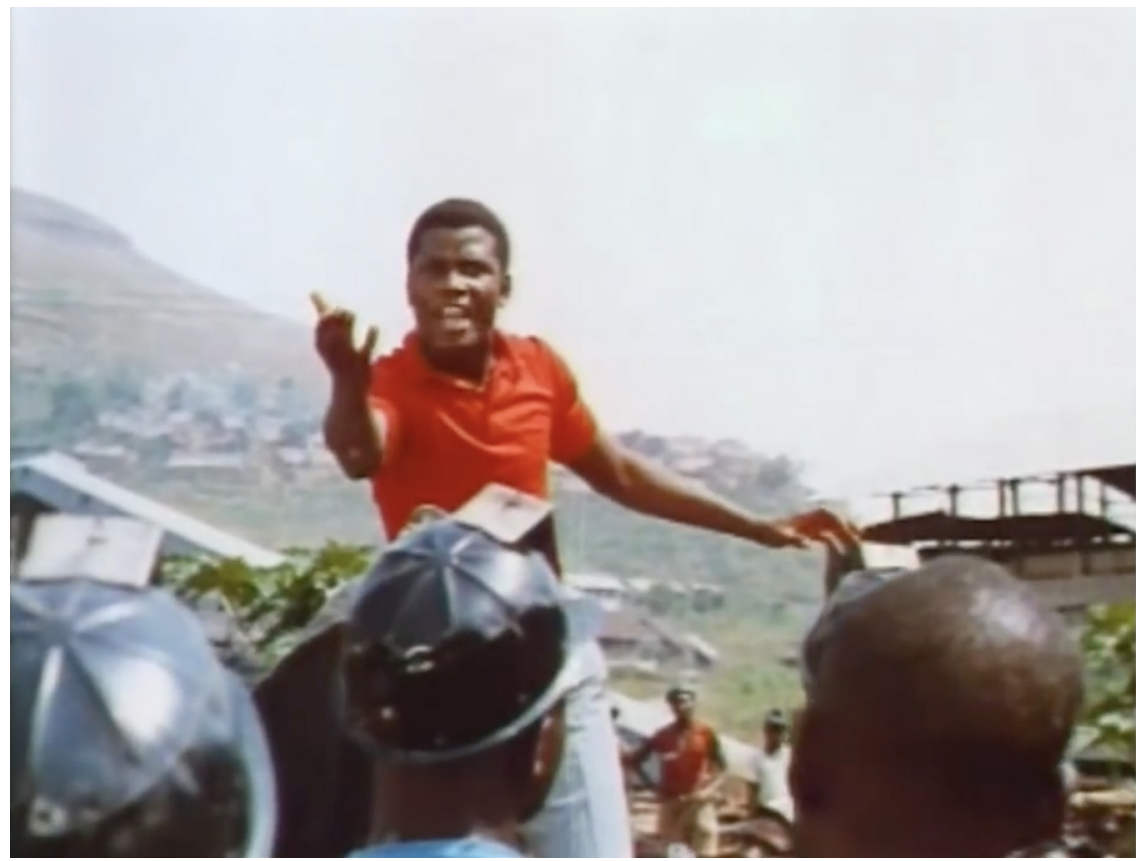

FIGURE 17. Poitier's Obam addressing the members of his trade union in The Mark of the Hawk.

Lest the film appear to endorse the initial impatience of the Poitier character, however, The Mark of the Hawk introduces a young African man whose "extreme views" are meant to suggest the dangers-the sheer destructive power-of radicalism, of "rushing." The Philadelphia Tribune would put the conflict in the clearest possible terms in its review of the film: this "realistic look at race relations in an unnamed African colony" centers on Poitier's Obam, "a Negro labor leader, who is torn between apparently fruitless peaceful efforts to win some measure of economic, political, and social equality for his people, and more direct and violent means to the same end." "Allied against him on one side," the newspaper continued, "is a segment of his own union, including his brother, who is bent on driving out the white man by terrorism and violence. On the other side stand some of Obam's white friends and associates on the governing council, and the cooler heads among the natives, led by an African Christian minister (Juano Hernandez).... Standing by through it all [is] a newly arrived American minister, who ultimately leads Obam to his decision for peaceful evolution rather than revolution." ${ }^{101}$

The Mark of the Hawk is thus an advertisement for liberal incrementalism-for "peaceful evolution rather than revolution." And, of course, "standing by through it all" - a constant, ever-watchful presence-is the American missionary, an envoy not only of Christ but of capitalism, and an outspoken enemy of any African who wants to "move too fast." ${ }^{02}$ Belittling Obam's "not-quite-African wife" (played by 
Eartha Kitt) and calling attention to his obsequiousness with certain members of the colonial regiment ("What are you-an Uncle Tom?"), Obam's brother, an "angry radical," is presented as entirely unsympathetic-a thorn in the side of the cause of decolonization, which, the film makes clear, will have to proceed along far less "strident" lines.

\section{PAVING THE WAY FOR POSTCOLONIAL CAPITALISM}

Whatever his credentials, and however pronounced his ambition, Lloyd Young was ultimately a mere instrument of Hollywood capital-a tool designed to gauge Enugu's receptiveness to American interests at a time when the city's growing significance could scarcely be ignored. Enugu's coal mines opened in 1915 and by 1948 were employing approximately six thousand workers. ${ }^{103}$ The 1938 designation of Enugu as the Administrative Headquarters of the Eastern Region ushered in a period of elite migration to the city, whose population swelled with non-indigenous government employees and "men of initiative in the professional, business, and service fields." 104 The income and living standards of these migrants to Enugu far exceeded that of the Udi indigenes who found employment mainly in the mines. ${ }^{105}$ Sidney Poitier's account of the socioeconomic inequality of Enugu is instructive, and worth quoting in full:

The majority of Enugu's population lived up in the hills in shanties and mud huts that overlooked the town below. In the mornings they poured down into the town by the hundreds to work for the middle-class blacks and upper-class Europeans who dominated the economic life of the region and could thereby afford to live in town, and at night they returned by steep and dangerous trails to places $a$ thousand years away. ${ }^{106}$

Strictly as a source of cheap labor, Enugu was scarcely different from those overseas filmmaking locations (like London and Rome) that have received considerably more attention in accounts of Hollywood's postwar internationalism. ${ }^{107}$ But the city was equally significant as a source of government assistance, and it served the additional purpose of providing an "exotic" (and thus widely marketable) backdrop, a documentary quality that Lloyd Young \& Associates could easily exploit.

Enugu discovered Young not by accident but because a research team at UCLA had identified him as a "film-industry expert" with an interest in "new and developing markets" like Nigeria. Young would eventually return the favor to UCLA, convincing Nigeria's federal government to send students to study film production at the school, all as "part of Nigeria's long-range program to establish a film industry for West Africa." 108 Even in the mid-1950s, then, Nigeria was envisioned as a source not simply of a national but also of a subregional film industry, one that would be explicitly patterned on Hollywood, with crucial postcolonial inspiration coming from India, which, in Young's tendentious telling, had made "amazing progress ... from scratch," becoming "a leading film production country in a 


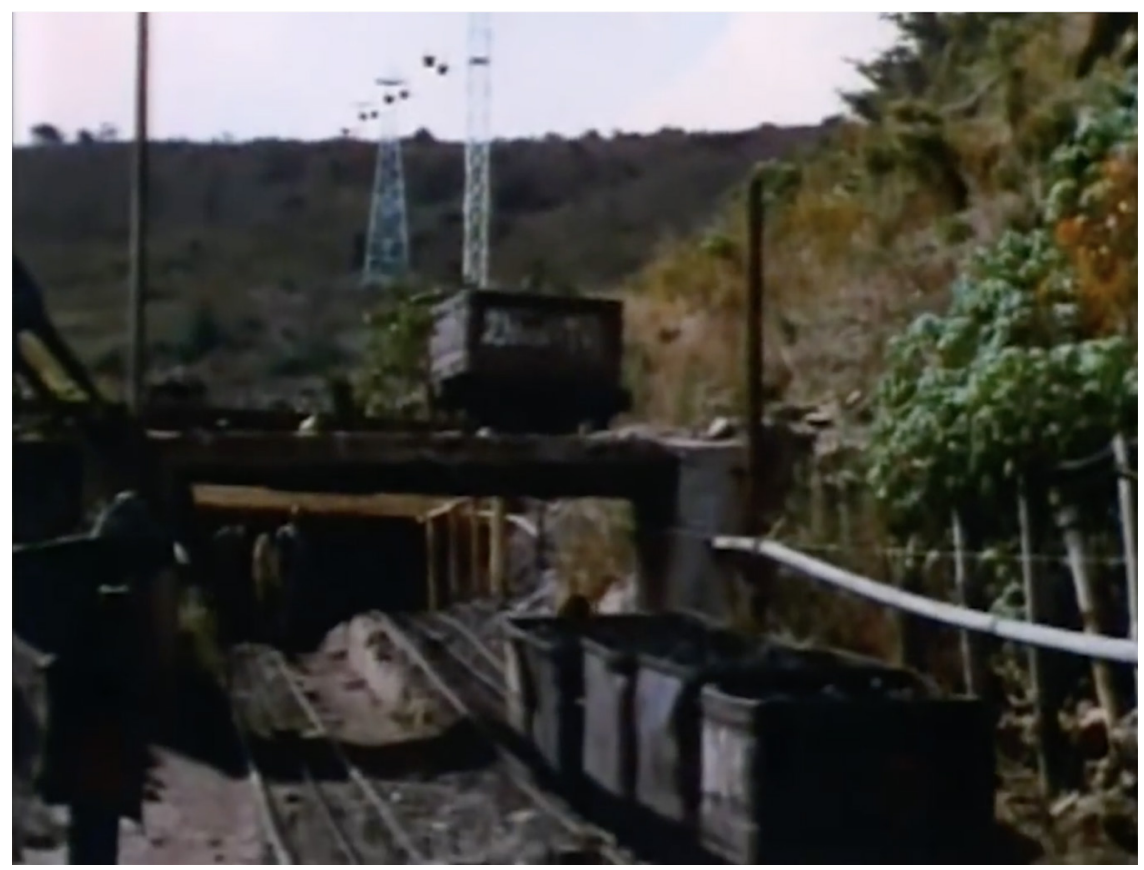

FIGURE 18. Enugu's coalmines in The Mark of the Hawk.

period of a little over 15 years." ${ }^{109}$ In keeping with Young's identification of India as a potential source of inspiration for Nigerian cinema (and a potential market for Nigerian films, given the long histories of Indian-African cultural and economic exchange), The Mark of the Hawk emphasizes the Indian presence in Nigeria, focusing on an Indian merchant class that is at once foreign and nonwhite, and thereby suggesting a truly global anticolonial struggle. Yet the Indian characters are agents of modernization strictly in the sense of promoting private enterprise. (They are hardly akin to the real-life Indian film censors who, as noted earlier, were moved to shield African expatriates from racist representations.) One Indian man, who manages a mine, thus serving as an engine of extractive capitalism for the near-exclusive benefit of Britain, urges the Africans to abandon their traditions (including their religion, with its alleged hostility to capitalism). He thus functions, ultimately, to help prepare the local ideological ground for the seeds of American-style capitalism.

That Young ended up not in Lagos but in Enugu speaks to the aggressiveness with which the Eastern Region pursued Hollywood-style filmmaking in the 1950s. Hollywood, for its part, was increasingly committed to identifying global opportunities for American capital. It was routinely abetted by African intellectuals at a time when, as Elizabeth F. Thompson argues, "American culture was not yet fully regarded as part of the hegemonic engine of . . European colonialism." 110 
Indeed, some of Africa's leading nationalists warmly welcomed Hollywood's incursions into the continent, reading these as rebukes to European colonialism-hence Young's strategic though scarcely convincing commitment, both in his script for The Mark of the Hawk and in statements made during the film's production, to distinguishing American capitalism from British mercantilism. ${ }^{111}$ Yet Young's venture came to embrace (in fact, to depend upon) the notion of a fiscally supportive host country. Poitier, for his part, later described Enugu as being "in every way a small town with visions of becoming a big city," and the breadth of its ambition was-by design-compatible with, and ultimately inclusive of, Hollywood's own aims. ${ }^{112}$

This was hardly a unidirectional process of enrichment, however. The Eastern Region government earned revenue, and gained institutional legitimacy, by providing accommodations for the members of the cast and crew, who stayed in a government-owned hotel designed to attract tourists. ${ }^{113}$ But such benefits were relatively meager or merely symbolic, and they certainly did not last. Poitier observed that in Enugu in the mid-1950s "a few banks [were] digging in for the anticipated growth of the years immediately ahead"-for an expansion that would stall by 1957, when Young and company simply fled, anticommunist film in hand. ${ }^{114}$

\section{THE ENUGU TANGLE}

"If any of you movie or TV producers are thinking of going over to Africa and making a picture with a supply of colored beads, some red calico cloth, and some sacks of salt, you had better redo your thinking. Times have changed in Africa. The beads better be from Van Cleef \& Arpels; the calico you can forget; and the only sacks the natives know is Saks Fifth Avenue."

- HAL BLOCK, “AFRICA SPEAKS AND HOW,” VARIETY, MAY 26, 1954

"It is sometimes claimed that the main sleight of hand for neoliberals is to hide the state, but even a cursory reading of the main theorists shows that a positive vision for the state is everywhere. The main thing . . neoliberals hide is not the state but asymmetries of power."

-QUINN SLOBODIAN, GLOBALISTS, 269

By 1957, the Eastern Region government had finalized its plans to make Enugu the "Hollywood of West Africa." 115 Now the hub of a dramatically different kind of filmmaking-a fount of low-budget, direct-to-video works that are clear and, in some quarters, cherished alternatives to the cosmopolitan polish of theatrically distributed New Nollywood productions-Enugu was, in Young's day, the source of a twenty-three-acre plot of "unused" land and the object of a \$24,000,00o investment by the government to turn that plot into a bona fide "film colony" modeled on Hollywood. ${ }^{116}$ The government-owned Cinema Corporation of Nigeria, with whose "cooperation" The Mark of the Hawk would be made, even commissioned a Los Angeles architect, Richard Neutra, to produce blueprints for studio facilities 
as well as for permanent four-walled alternatives to open-air cinemas like the Roxy and the Emy. ${ }^{117}$

Upon arriving in Nigeria, Young immediately issued his request for experienced American "film technicians," writers, and directors who would be willing to relocate to the decolonizing country for up to three years. As Variety put it on Young's behalf and at his behest, "In addition to aiding in organizing a local film production program, the American creative talent and technicians will, of necessity, have to serve as instructors to train local citizens in the mysteries of filmmaking." 118 Though Young's call for behind-the-scenes labor came with no racial stipulations, his associated request for performers suggested not only an ignorance of Nigerian theatrical talent but also an eagerness for "American Negro actors" (as he called them) to portray Nigerians on film. The Mark of the Hawk would ultimately suggest a somewhat more expansive, even prototypically Pan-Africanist gesture, with a cast that, though it boasted no credited Nigerian performers, included the Bahamian-American Sidney Poitier, the Afro-Puerto Rican Juano Hernández, the Bermudian-British Earl Cameron, and the American Eartha Kitt. When the West African Students' Union (WASU) spoke out against the filmmakers' failure to cast Nigerian performers, it echoed the complaints that its members had made some sixteen years earlier, upon the completion of the CFU's An African in London (1941). Anticipating the Nollywood classic Osuofia in London (Kingsley Ogoro, 2003) by over half a century, the CFU short purported to show a wonderstruck Nigerian's eye-opening tour of the imperial center, but, in sharp contrast to its direct-to-video descendant-and much to WASU's chagrin-it featured a Guyanese actor, Robert Adams, in the title role. ${ }^{119}$

Made on location in Nigeria but starring a constellation of foreigners, The Mark of the Hawk could not help but recall, and reanimate, such controversies. If the film's cast suggested a Black internationalist network of stage and screen talent, it was a network that did not extend to Nigerians. Among the film's extras, however, was nine-year-old Kalu Kalu, described in the American press as "a top scholar in English at the local missionary school." The Mark of the Hawk made the boy "a hero in the eyes of the citizens of his hometown, Enugu, Africa," as the Los Angeles Times put it. ${ }^{120}$ "The hero of Enugu," echoed another newspaper, "is only nine years old, but to his townspeople he's already a great man. For key location scenes in Africa for [the] Lloyd Young \& Associates production ... a young native who could speak English well enough to carry dialogue [stepped] into the magical world of moviemaking. And because the film company spent their location in his home town, Enugu, the boy became a celebrity." ${ }^{121}$ But, for all the press's emphasis on Kalu Kalu's English skills, his was not a speaking part, and whatever publicity he received was, of course, vastly overshadowed by that accorded Kitt and Poitier.

Rather than providing major opportunities for Nigerian actors, Young's production plans would, in a paternalist gesture, require "American Negros" to "model" film acting for "untutored" Nigerians. ${ }^{122}$ In this sense, Young's reliance on Enugu 


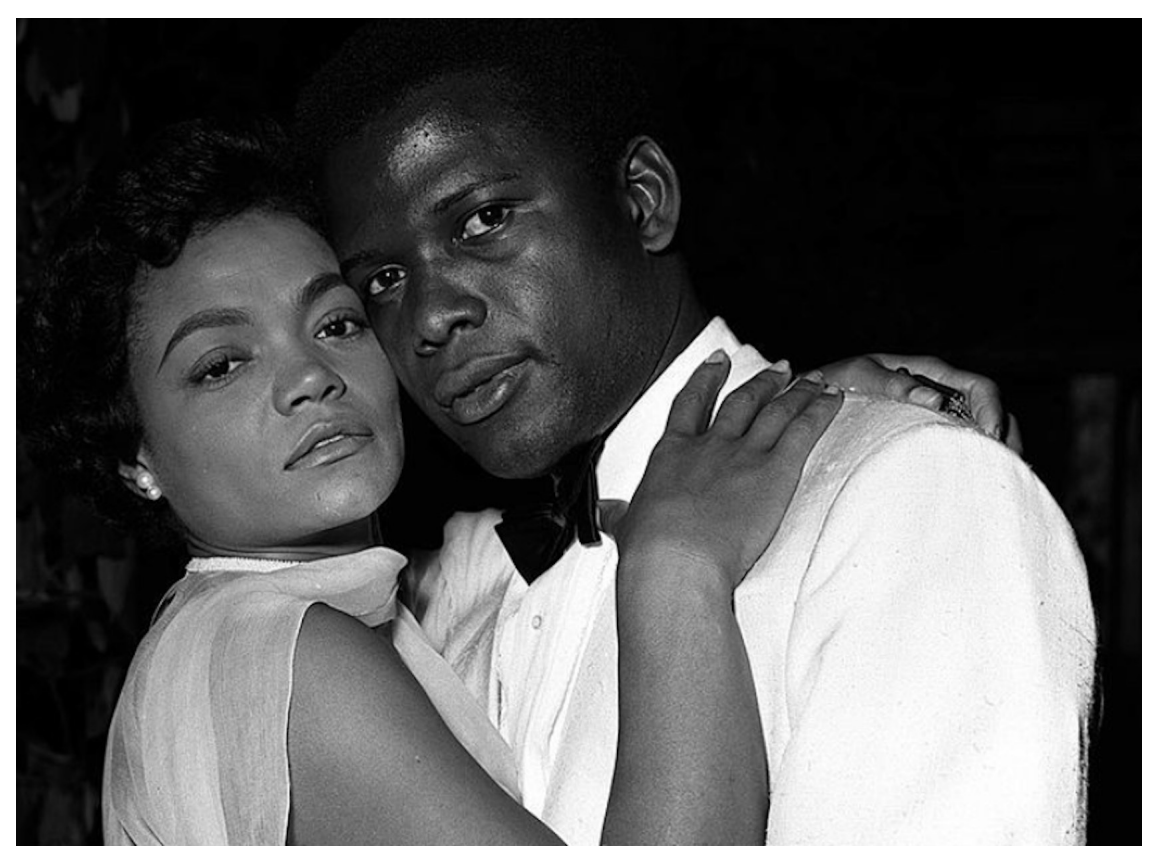

FIgURE 19. United in Enugu: Eartha Kitt and Sidney Poitier, the stars of The Mark of the Hawk. Author's collection.

to subsidize-and serve as the principal shooting location for-The Mark of the Hawk contrasted sharply with the terms and conditions of the roughly contemporaneous Eady Plan, by which the British government sought to provide financial assistance for foreign films with the requirement that they be filmed in Britain with a mainly British cast and crew. ${ }^{123}$ Young had in mind the production in Nigeria of just one feature film per year, of which The Mark of the Hawk, though made by an American company with the mere "cooperation" of the Cinema Corporation of Nigeria, would represent the first.

Young's self-serving celebrations of decolonization did not prevent him from turning to Britain for crucial post-production assistance. Such help would eventually arrive in the form of the Associated British Studio Orchestra, which furnished the instrumental score for The Mark of the Hawk. Equally useful were the Associated British Picture Corporation studios in Elstree, England, where reshoots and rerecording occurred. Working out of Elstree, Young incorporated his Nigerian footage-including hundreds of feet of film recorded on location in Enugu by a second unit-into matte process shots. Adding interimperial insult to Enugu's injury, Lloyd Young \& Associates would later take out a full-page ad in The Hollywood Reporter thanking the Associated British Picture Corporation for providing expert postproduction services on The Mark of the Hawk. This "vote of thanks" was, in its own way, an expression of doubt regarding Enugu's infrastructural 


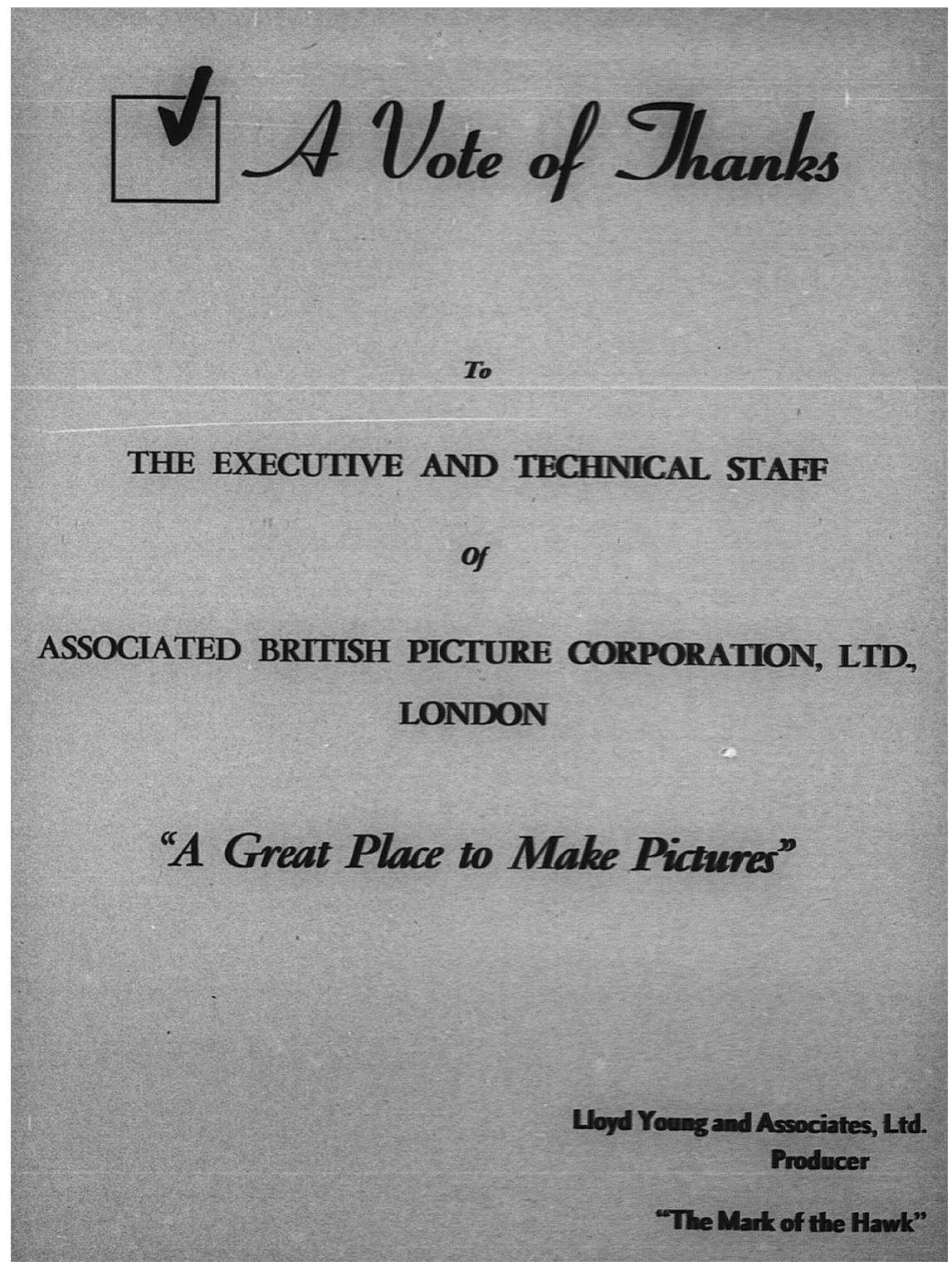

FIGURE 20. Lloyd Young's full-page ad in The Hollywood Reporter made no mention of Nigeria.

capacity-a sign of the very underdevelopment to which Lloyd Young \& Associates had contributed. Calling London, rather than Enugu, "a great place to make pictures," the company only reinforced (through the Hollywood trade press, no less) a sense of Nigeria's dependence on Euro-American capital. ${ }^{124}$ 
However much The Mark of the Hawk may have served the interests of British firms, American companies stood to benefit the most from the film's production and global distribution. Lloyd Young \& Associates cannily availed itself of Technicolor and Superscope-the latter a "widescreen process applied at the printing stage rather than during photography, demanding adjustments to existing theatre projection equipment rather than the installation of new equipment, as was the case with processes such as CinemaScope." While the Superscope image "tended to lose definition and was regarded as inferior to other widescreen processes because of this image degradation," it was nevertheless considered a cutting-edge technique at the time The Mark of the Hawk was made. Its marketability had recently been demonstrated by United Artists, which had distributed Robert Aldrich's Vera Cruz (1954), shot on location in Mexico and the first Hollywood feature to be released in Superscope. ${ }^{125}$ As Emily S. Rosenberg points out, displays of technological sophistication were, within the framework of liberal-developmentalism, thought to augur "a new Christian age in which all peoples of the world would progress toward prosperity." 126

Technicolor and Superscope served precisely this purpose in the case of The Mark of the Hawk, constituting a kind of "Hollywood sublime"-an American variant of the "colonial sublime" described by Brian Larkin in his work on British technologies of transportation and communications in Nigeria. ${ }^{127}$ The novelty of applying Superscope and Technicolor to specifically African subject matter was not lost on Young, who, in keeping with his ideological-diplomatic mission, expected these "awesome" technologies to serve as overwhelming advertisements for capitalism. ${ }^{128}$ Something similar was at work with Giant in the Sun, a 1959 production of the Northern Nigerian Information Service that, under the direction of British filmmaker Sydney Samuelson, relied on Eastmancolor, Kodak's single-strip multilayered color negative film, known for producing a sharper image than Technicolor's dye-transfer process. ${ }^{129}$ Young's project promised to pull Enugu, and by extension all of Nigeria, into a filmic modernity marked by Superscope and Technicolor-as well as by public-private partnerships and a commitment to global distribution. ${ }^{130}$

\title{
ECONOMIC MODERNIZATION IN ENUGU
}

\author{
"The economics of decolonization remain to be explained." \\ -FREDERICK COOPER, "AFrica AND THe WORLD ECONOMy," 141
}

Via the Macpherson Constitution of 1951, the regions of Nigeria-previously mere administrative divisions - were transformed into bona fide political and governmental systems, complete with executive councils and legal assemblies. ${ }^{131}$ The Western and Eastern Regions of Nigeria obtained internal self-government in 1957, when The Mark of the Hawk was in production in Enugu. During that decade, Nigeria's gross domestic product increased at an average annual rate of more than 
4 percent. ${ }^{132}$ Foreign investment expanded and intensified in direct response to a spike in effective demand occasioned by a rise in national income levels. ${ }^{133}$

Nigeria's ongoing pursuit of a modernized economy unfolded, in other words, both federally and regionally, and it was not without discrepancies. For instance, in its specific development strategy, Enugu attached a uniquely high priority to cinema as a mechanism of modernization. "The rationale of regional autonomy was that it would enable each region to develop according to its own pace until differences among them were eliminated," wrote the Nigerian political scientist Eme O. Awa in 1964. ${ }^{134}$ But the homogenizing potential and equalitarian purpose of regionalism did not prevent the development of some rather striking asymmetries, including in the realm of "film development." 135 "The regions have been in keen competition with one another," Awa noted, "particularly as between east and west. The government of the Western Region has maintained a clear lead in most activities because of its stronger financial resources, better planning, and the help of a very able team. Labeled a poor region, the east has been concerned to show that it is not so poor as many people have been led to believe, and in planning and carrying out certain programs it has not always related them as precisely as possible to available resources." 136 The Mark of the Hawk was meant in part to improve the Eastern Region's national reputation, whatever the compromises involved in the film's production. Investing in Hollywood, and with it the rhetoric of private enterprise, was a way for Enugu to show that, at the very least, it was "not so poor" a source of cinematic fantasies as proponents of media-rich Lagos had been willing to admit. Hollywood capital could, in the short term, be counted on to lend Enugu an impression of connectedness to the wider world - and, in particular, to the idea of commercial theatrical film-that it could then exploit politically.

For its part, the American political discourse on decolonizing Nigeria was increasingly attuned to regional distinctions. "At the moment Nigeria is under a federated system of government which permits each of the three Regions-Eastern, Western, and Northern-considerable autonomy," noted a US Senate subcommittee in 1957, reporting on a study undertaken in 1955, just prior to the making of The Mark of the Hawk. Proceeding to single out Enugu for special praise, the subcommittee made clear that the Eastern Region was ripe for exploitation by American companies; it pointed out that "the rudimentary family or clan authorities typical of the politically fragmented peoples of the east" stood in sharp contrast to both "the large and highly organized emirates of the Islamic north" and the "developed chiefdoms of the Yoruba country" to the west. The sheer "concentration of Negros in Igboland" was, according to the subcommittee, another advantage for companies looking to cultivate consumers. "Our mission was happy to learn," it continued, "that large numbers of students in the Eastern Province were being assisted in studying in the United States." Technical training programs offered a means of rationalizing the exploitation of "underdeveloped" countries like Nigeria, which had been sending promising students to American institutions 
for decades. The subcommittee stressed that Nnamdi Azikiwe was himself "educated primarily in the United States," and, without going so far as to embrace Leninist theories of imperialism, it praised Azikiwe's West African Pilot for its "frequent criticism of English policies" and for "extolling the racial consciousness of a free African Africa."

When the subcommittee sent its special "fact-finding" mission to Nigeria in 1955, Enugu was its second destination after Lagos. When the mission was in Enugu, Azikiwe was in the United States-a coincidence that the subcommittee took (or at least touted) as a sign of shared goals, a symbol of mutuality and exchange. It claimed that Azikiwe was "obsessed with the idea of improving the Eastern Region by bringing industry into it ... on the American pattern." The "peoples of this province are called the Yankees of Africa due to their trading ability as well as their political maturity," asserted the subcommittee, which also emphasized that its mission had been impressed by the media literacy observed there. ${ }^{137}$ For all its contradictions (the Igbo were at once "politically fragmented" and "politically mature," "rudimentary" and "sophisticated" in their systems of oversight), the subcommittee's rhetoric centralized Enugu's significance to American neocolonial aims, offering a distinct legislative expression of the sort of ideology promoted in and through The Mark of the Hawk.

Characterized by Sidney Poitier as a "small independent film producer seeking to move up to the big time," Lloyd Young had long been interested in distinguishing himself via association with an "exotic" land-a place (like Enugu) to which no Hollywood filmmaker had gone before. ${ }^{138}$ After finishing The Mark of the Hawk, Young would go on to India, where he hoped to make a film about Gandhi, his commitment to Nigeria and Nigerians suddenly revealed to have been fleeting at best, merely an inaugural stage in his company's efforts to brand itself as a producer of "serious" films about global decolonization. Enugu had managed to meet Young's capital requirements, and Young simply walked away.

The peripatetic writer-producer cultivated an image of himself as a particularly powerful figure, a new Selznick, Thalberg, Goldwyn, or Wanger. The name of the nominal director of The Mark of the Hawk-Michael Audley-almost never appears in the archival record, which emphasizes Young's authorship at every turn, and in keeping with Young's own strategies of self-presentation. ${ }^{139}$ Audley, an American, had never directed a feature film before and would not direct one again. He appears to have been selected by Young precisely for his capacity to do the writer-producer's bidding, although it is unclear why Young refrained from officially taking the directorial reins himself. In any case, Young, as creative producer, "was involved in all facets of production," and The Mark of the Hawk surely bears his stamp; it was, after all, his brainchild, and Nigeria was, he alleged, the only place in which he could imagine filming his story of capitalist nationalism. ${ }^{140}$ “'The Mark of the Hawk,' produced and written by Lloyd Young, mixes reason with violence in its attempt to view fairly from all sides the problem of nationalism 
in Africa," wrote the Philadelphia Inquirer in its review of the film. "The case for the African, as well as the white man of good will, is put with great power in the literate, open-minded script." 141 That Young could be considered a "white man of good will" was central to the film's international promotional campaign, and his prominence in the Inquirer article is telling. The Inquirer did not mention Audley until the closing sentence and then suggested that he, in contrast to writer-producer Young, merely coached various members of the large cast. Most American journalists in turn emphasized Young's authorship, as critic Mildred Martin did: "Produced and written by Lloyd Young, this gorgeously photographed, Nigerianshot drama is a many-sided study of the various elements for good and evil in an unnamed British colony in Africa." ${ }^{142}$

Young was one of postwar Hollywood's more opportunistic independent producers_ “an indefatigable scrambler out of Burbank, California," Poitier called him. ${ }^{143}$ Though a relatively small-scale entrepreneur, he had powerful allies in Hollywood and Washington, and his infiltration of Enugu reflected "the growing confidence of corporations that they could bring pressure on any kind of government." ${ }^{144}$ Like the film itself, the making of The Mark of the Hawk represented the strategic melding of neoliberalism and the spiritual mission associated with Protestantism, which, beginning in the nineteenth century, attempted, throughout the African continent, to replace "primitive kinship arrangements" with "an inwardturning individualism, one that sought salvation and worldly success strictly as a private pursuit." ${ }^{145}$ An agent of this strategic fusion, Lloyd Young \& Associates was a "footloose" firm in an era "in which an unprecedented mobility of capital and production ... enabled corporations to constantly seek - and find-friendlier and friendlier business environments." 146 The "friendliness" of Enugu was not a given, however; it had to be cultivated, albeit without much, if any, input from ordinary Nigerians. "Tellingly, Africans were rarely, if ever, in the 1950 s consulted on development options for their own continent," writes Inderjeet Parmar. ${ }^{147}$ The making of The Mark of the Hawk-a public-private initiative meant to promote "modernization"- suggests a cinematic equivalent of American foundations' efforts to "develop" Nigeria with the full cooperation of the Nigerian state.

It was far from the first. In the late 1940s, for instance, the Canadian-born Hollywood filmmaker Julian Roffman had produced A Greater Tomorrow (also distributed under the title The Greater Tomorrow of the African Peoples), a twenty-fiveminute documentary made for use in Nigeria, where it was frequently screened in association with the political activism of the Nigerian nationalist K.O. Mbadiwe. ${ }^{148}$ Commissioned by the African Academy of Arts and Research, a Nigerian-American cultural-exchange program co-founded by Mbadiwe and Mbonu Ojike, $A$ Greater Tomorrow anticipated Young's efforts to secure, embody, and convey the connectedness of Nigeria and Hollywood. Its explicit purpose to "promote cultural and economic understanding" between Nigeria and the United States, A Greater 
Tomorrow was widely screened in both countries-a cinematic advertisement for precisely those benefits that Young would eventually obtain from Enugu. ${ }^{149}$

Influenced by Enugu's ambitions, which it also helped to shape, Young's venture in turn anticipated Eme O. Awa's argument that, in Nigeria, "the regions are a proving ground. Within their respective areas they may pioneer and experiment under the impulse of local demand, without waiting until the entire nation is convinced of the wisdom of the measures." 150 The Eastern Region's development planning, with its emphasis on improving the standard of living of its inhabitants, explicitly included the idea of film spectatorship, a fantasy of cosmopolitanism premised on the existence and expansion of a moviegoing middle-class. But its attention to questions of employment in film production, distribution, and exhibition was inadequate at best, with the result that local unionized labor was not at all represented in the making of The Mark of the Hawk, a film whose plot in fact pivots around the alleged inadequacies of trade unions and the need to submit to the "expertise" of unfettered American capital.

In 1961, an American trade paper wrote of "the realization on the part of its leaders and educated class that Nigeria can best achieve its goal of leadership in Africa under a free, private-enterprise system which encourages foreign investment and technical skills." ${ }^{151}$ As one Nigerian government official told the Wall Street Journal at the time, "Nigerians think anything American, whether it is a product or advice, is bound to be better than anything else, including anything British." ${ }^{152}$ Requests for foreign capital continued apace. As the West African Pilot put it, "the Eastern Region stands ready to help foreign businessmen set up new industries here." ${ }^{153}$ "Eastern Nigeria has always been foremost in acknowledging the absolute need for overseas capital, technical know-how and managerial skill," said Nnamdi Azikiwe upon the completion of The Mark of the Hawk. "It has never concealed its belief that the only way of attracting [these] is to ensure for those who provide them unstinted cooperation, confidence, security, and opportunities to earn adequate rewards." ${ }^{154}$ In 1962, Chief B.C. Okwu, the Eastern Region's Minister of Health, proclaimed, "We need foreign capital," adding that Enugu "would welcome all investors with a genuine desire to play a part in [its] development programme." 155 The West African Pilot aptly termed this an "intensive campaign ... to lure foreign capital in an all-out effort to accelerate [the Eastern Region's] economic development." 156

Americans were not the only bearers of "development assistance" during the crucial years of decolonization. In some cases, Nigerians who had studied in the United States were bringing American-style capitalist expertise back to their homeland, and were determined to modernize the country along stridently anticommunist lines. Such efforts occasionally assumed an explicitly Christian character, recalling the participation of the Presbyterian and Methodist churches in the production and promotion of The Mark of the Hawk. After receiving a PhD 


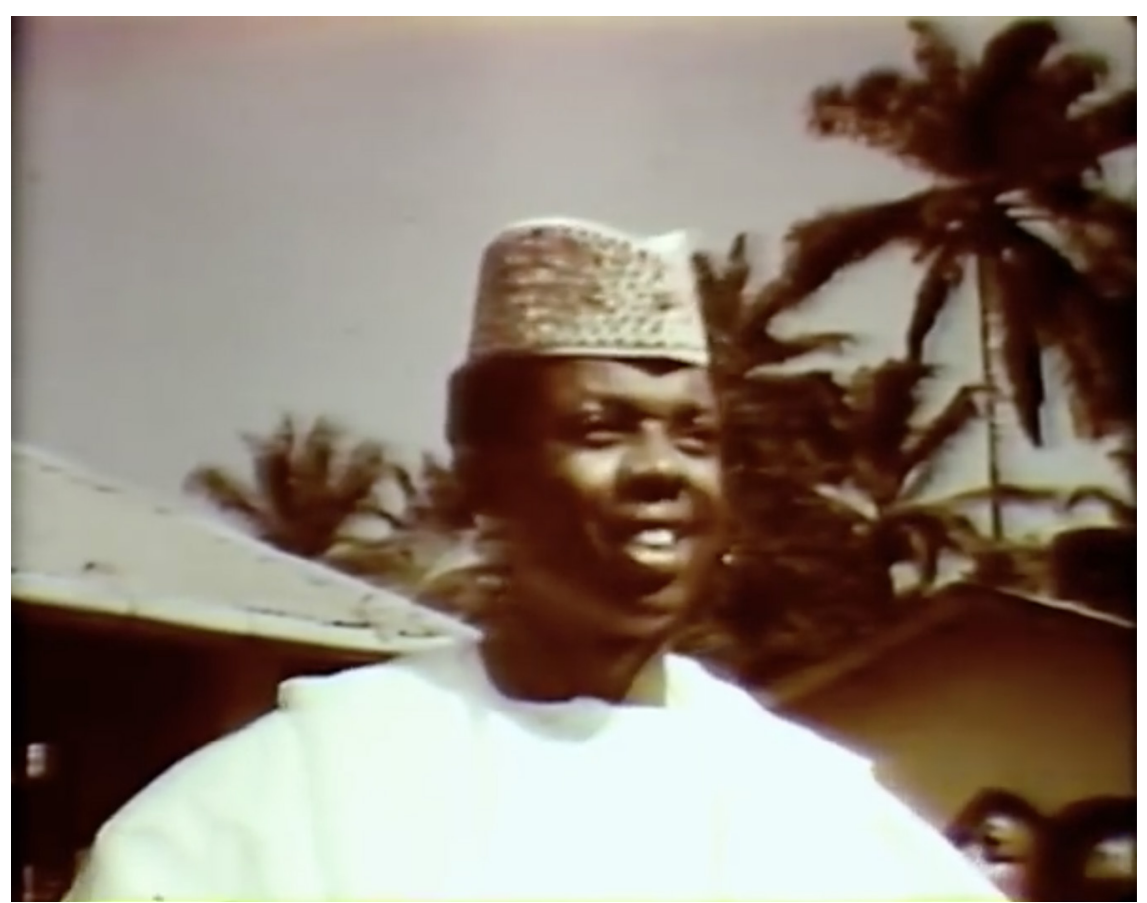

FIGURE 21. After earning a doctorate from Cornell University, B.U. Nzeribe triumphantly returns to his native Nigeria in A Village Is Waiting (1962).

in economics from Cornell University in the 1950s, Benjamin Uzoukwu Nzeribe appealed to the Unitarian Service Committee, a nonprofit organization based in Cambridge, Massachusetts, to invest in — and make a film about-Awo-Omamma, a village in southeastern Nigeria, where Nzeribe was born and raised. The resulting documentary, entitled A Village Is Waiting (1962), was filmed by an American volunteer, Erica Anderson, and narrated by Nzeribe himself.

Outlining the need to "modernize" Awo-Omamma, Nzeribe explains why he requested American assistance. "I recognized the job of building our village would take more than our limited resources," he says over Anderson's images of his birthplace. "For this reason, I appealed for outside help, and the Unitarian Service Committee listened to me, considered what I had to say, came forward, offering us both financial and technical aid. Here was mutual respect and belief"-nothing less than "a partnership in the progress of men." Filmed in color, the thirty-minute A Village Is Waiting was widely distributed by the Unitarian Service Committee, which shipped free $16 \mathrm{~mm}$ prints out of its Boston offices and even licensed the film for television. ${ }^{157}$ "Progress does not lie in buildings," Nzeribe explains in his voice-over narration, even as the film's image track lingers on literal construction. "Buildings are only its manifestation. Progress comes when there is a change in the hearts of men." In A Village Is Waiting, as in the earlier The Mark of the Hawk, that 


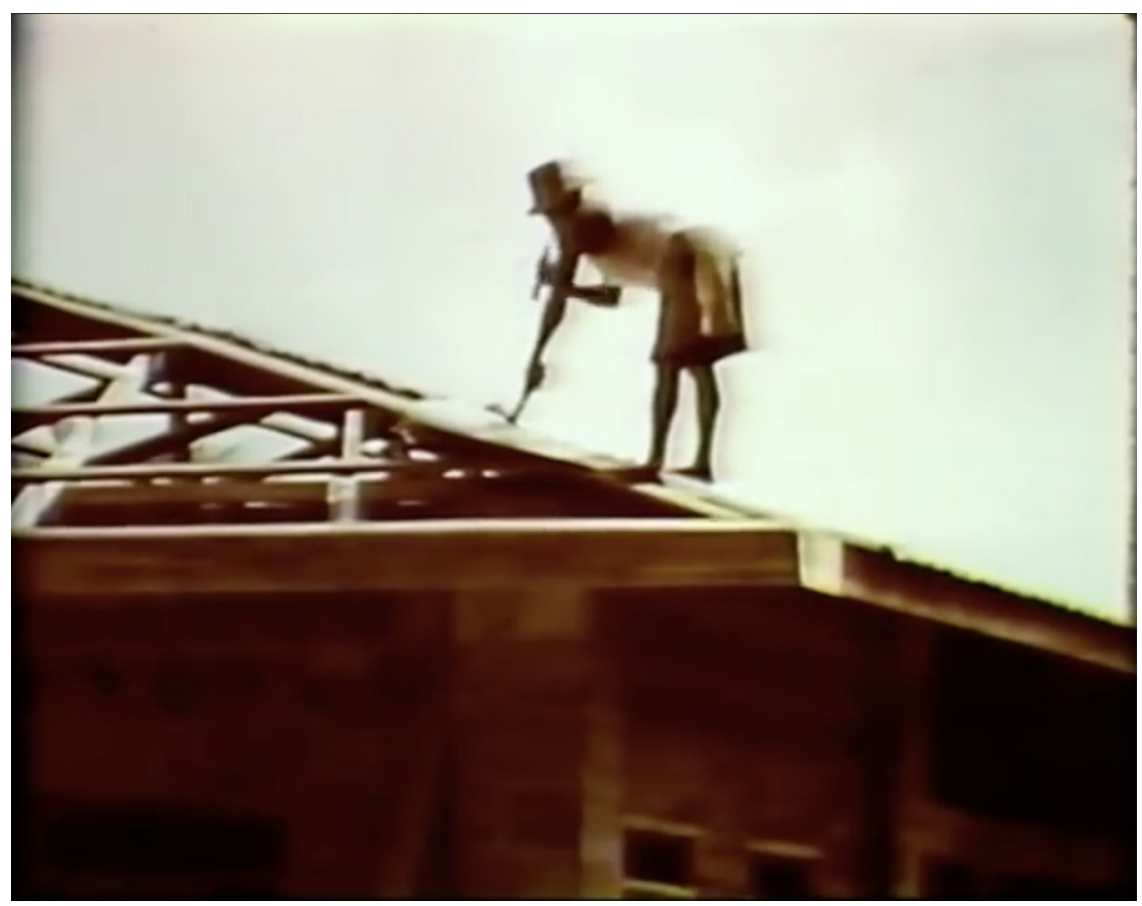

FIGURE 22. Literal construction in A Village Is Waiting.

change is understood to be a matter as much of Christianization as of a decisive turn toward capitalist anticommunism.

\section{PROTESTING HOLLYWOOD}

Enugu's generous concessions to Young's production were made at a time when the former was actively searching for revenue streams that were independent of the federal government, on which it otherwise relied (including for a share of oil revenues). But Enugu had to contend-particularly after the Bandung Conference of 1955, which inaugurated a Third World Project rooted in shared Asian and African concerns about "the failures of capitalist mal-development" - with popular opposition to foreign domination of the economy, or what one Nigerian economist called a "public outcry against foreign investors" like Young and his fellow filmmakers. ${ }^{158}$ The trade unions then active in the Eastern Region were especially robust, containing anticolonial as well as anti-American elements. Many of these unions had been established after World War II, but some had deeper roots: the Women's War of 1929-part of a broader anticolonial uprising-had been led by some of the very unions that were flourishing in and around Enugu in the 1950s. ${ }^{159}$ Desperate to reduce social unrest and to appease the unions, the federal 
government responded to nativist sentiments by seeking to protect only the retail trade from foreign domination-a relatively small concession that left the film sector open to the sort of domination that the Nigerian Film Unit, as indigenous successor to the Colonial Film Unit, was ostensibly designed to sidestep beginning in the late 1940 . ${ }^{160}$

If the federal government believed that Nigerians could "efficiently handle" the retail trade-and, more to the point, that foreigners would hardly be miffed at their exclusion from it-Enugu was committed to the notion that only Hollywood "experts" were sufficiently skilled to oversee the development of a regional film industry. Through its technocratic conception of film production, distribution, and exhibition, the Eastern Region anticipated Léopold Sédar Senghor's controversial conception of technicité-or the technical spirit-as, in Noémi Tousignant's words, "a quality to be imported and assimilated to enable a full, yet distinctive, African participation in modernity." 161 That Young would be unable or unwilling to pursue the cultivation of a local film industry was, however, not lost on Nigerian critics at the time. Hollywood, UCLA, and the State Department may have presented Young as uniquely committed to "film development," and Enugu may have been all too eager to believe in him, but many saw the visiting American as simply the latest in a long line of propagandists committed to the normalization of capitalism as well as to the attendant underdevelopment of production infrastructures on the African continent. "Understanding and cooperation between [Hollywood and the African people] are indispensable to African development, but Hollywood has elected from the year of its birth to undermine and destroy the very basis of African development," wrote Oladipo Onipede during the making of The Mark of the Hawk. ${ }^{162}$ Onipede's was one of the most prominent and prescient voices warning Nigerians to be wary of Young and what the enterprising American-a particularly chipper ambassador of capitalism-represented.

Onipede's remarks powerfully illustrate that Nigerians were not passive recipients of American modernization paradigms but, in some cases, actively contested them. That Young posited his plan as an alternative to British colonial modernity-as, that is, a demonstration of allegedly anticolonial US interest in Nigeria-did little to alleviate Onipede's concerns. Regional development did not, from Onipede's perspective, require what Young was proposing. A "partnership" between African capital and American know-how was hardly necessary when Igbo modernity offered its own forms of expertise, economic and otherwise. An implicit critique of Britain's colonial governmentality, The Mark of the Hawk represented the American cooptation of Enugu's emergent regionalist efforts. Yet rational regionalist planning, Onipede insisted, could easily have been pursued in the complete absence of Hollywood-inflected modernization paradigms. That it was not struck Onipede as a distinctly bad omen for the development of a truly autonomous Nigerian cinema.

Highlighting what he termed "Hollywood's holy war against Africa"-a "symbolic slaughter" not simply of the possibility of socialist development on the 


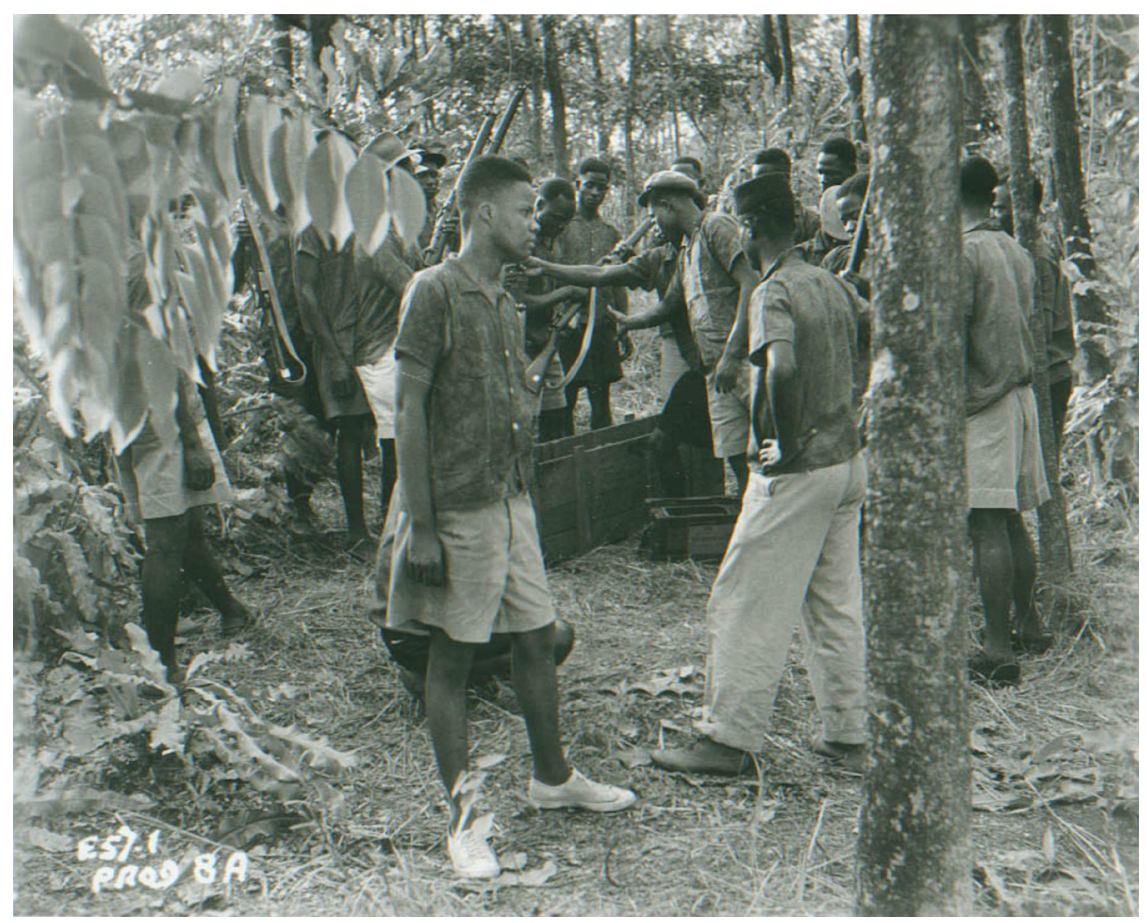

FIGURE 23. Nigerians performing below-the-line labor on The Mark of the Hawk, shot on location in Enugu. Author's collection.

decolonizing continent but also of the material and ideological opportunities for African films forced to compete in a marketplace dominated by imports and dictated by foreign capital-Onipede did not mince words. "It would be putting it mildly to say that Hollywood has engaged in an unrelenting propaganda war against the African," he wrote. His denunciation of oyinbo pelu jibit-roughly, the white man and his disinformation-clearly encompassed Young and company, and, in particular, their Christianized attempts to pathologize socialism and valorize capitalism for their own gain (and certainly not for Enugu's, despite their many claims to the contrary). ${ }^{163}$

Onipede was especially alert to inequalities within Nigeria-to the dangers of regionalism, which, in his view, were only exacerbated by the work of men like Young and his associates, all of them unfamiliar (or simply unconcerned) with the experiential gaps between rich and poor, urban and rural:

Here it must be pointed out that movie-going in most of Africa is very much limited to the urban centers. The latter have been exposed to the impact of westernization. Consequently, the city dweller considers himself more sophisticated than the rural dweller. The reaction of the former to the trite Hollywood myth is dual: either he dismisses it as the same old attempt of the white man ... to convince himself of how backward the African is. Or, if the city dweller is highly westernized, he would 
immediately transfer the symbol of the 'savage African' on to some other mythical corner of Africa where 'savages' still live on trees and in caves. However, the average city dweller cannot ever believe for one moment that Hollywood could ever dare to portray him that way. ${ }^{164}$

Onipede may have underestimated the significance of nontheatrical distributionof the mobile cinema units and other mechanisms for bringing motion pictures to the rural communities that were, through these very efforts, hardly unaffected by the "impact of westernization" (especially considering the consumerist function of the "interpreters" and other marketers associated with the cinema vans in Nigeria). But his comments suggest the obvious discrepancies between the Eastern Region, however population-dense and subject to increasing urbanization, and such places as Lagos and Ibadan, to which foreign capital paid perhaps the closest attention at the time.

"Hollywood's distortions" may, Onipede pointed out, "have been the subject of heated debates" in the Nigerian legislatures, but those debates led, in Enugu, to the rather fanciful conclusion that Young and other "independent" producers could help to correct the representational missteps of their compatriots and, more importantly, materially and epistemically assist the Eastern Region in its cinematic ambitions. ${ }^{165}$ Despite the failures associated with the local production of The Mark of the Hawk-chief among them Young's inability (or refusal) to help establish a viable film industry in Enugu-belief in the virtues of economic liberalization continued to animate Nigerian policy at federal as well as regional levels. On the eve of the Biafran Civil War, the political economist R.S. May wrote, "Given the maintenance of liberal economic policies, political stability and unity, Nigeria should continue to benefit greatly from the presence of international companies." ${ }^{166}$ But it was not the war alone-not simply the conflict's disruption of "political stability and unity" - that prevented these "great benefits" from materializing. ${ }^{167}$ It was also, as the making of The Mark of the Hawk attests, the very "presence of international companies" said to be eminently capable of generating local growth and prosperity.

Critics of the particular political economy that enabled Young's production would later lament "the incentive measures provided by government to [foreign] investors and entrepreneurs without any selective criterion"-measures that had "succeeded only in enabling certain firms to amass profits at the expense of the tax-payers." 168 Young was brought in as precisely the kind of development "expert" who would become prominent in Nigeria in the aftermath of independence. He presented a vision of his own enrichment and career advancement, disingenuously couched as attention to Nigeria's "development needs", and his scant knowledge of Nigerian cultures - a relative ignorance remarked upon by Poitier, Onipede, and others-led some government officials to reassess the qualifications required of foreign investors and push for administrative reform. Nearly fifty years later, the National Film and Video Censors Board would announce "the need for [foreign] 
participants [in Nigeria's film sector] to acquaint themselves with the nature of our society so as to know what to produce and what not to." This statement echoes Onipede's remarks about American filmmakers like Young who, at a time of seismic political change in Nigeria, were committed to the country only to the extent that it could fill their coffers and advance their careers. ${ }^{169}$

The Eastern Region government was clearly complicit in these efforts, however, and its entanglement with Lloyd Young \& Associates-the precise partnership that it fostered with Hollywood capital—recalls the economist John Quiggin's remarks about some of the shared failures of state institutions and private enterprise. "Public sector investments, from the time of the Pharaohs onward, have included plenty of boondoggles, white elephants, and outright failures," writes Quiggin. "But the private sector has not done better. Waves of extreme optimism, leading to massive investment in particular sectors, have been followed by slumps in which the assets built at great expense in the boom lie unfinished or idle for years on end." 170 The twenty-three-acre, twenty-four-million-dollar Enugu "film colony" planned by the government-owned Cinema Corporation of Nigeria, which bore no fruit beyond the production of Young's The Mark of the Hawk, was, in its own way, an augury of failures and false starts to come. These include Tinapa Studios, part of a twenty-acre, 450-million-dollar government project in Calabar, the capital of Cross River State (and the original capital of the Eastern Region). Tinapa, which opened amid much fanfare in 2007 and was meant, in part, to compete with Lagos as a tourist destination and source of imported luxury items, now lies derelict, the promise of tax exemptions for participants in its economy an unrealizable echo of various (and similarly misguided) forms of government assistance.

In 1985, Nigerian filmmaker Ola Balogun recognized that the concept of a "film village" was nothing more than a "red herring," one that "need not occupy anybody's time or attention": "Huge capital investment in real estate development is certainly not an essential prerequisite for film production, no matter how impressive it may sound to some of us to hear of gigantic film villages (or white elephant villages?)." ${ }^{171}$ For even if Tinapa were fully operational, it would not directly contribute taxes and other benefits to the local economy. Like Eko Atlantic, it was designed to serve as an economic "free zone" and thus evokes Enugu's failure to levy taxes and impose restrictions on Lloyd Young \& Associates (such that the company's gain became-inevitably—the Eastern Region's loss). ${ }^{172}$ Like Enugu's planned "film colony" of the 1950s, Tinapa has facilitated the production of just one feature-Biyi Bandele's Half of a Yellow Sun (2013), which, like The Mark of the Hawk before it, is only tenuously Nigerian. Bandele is based in Great Britain, and the film's producer, Andrea Calderwood, is perhaps best known for the Oscarwinning The Last King of Scotland (Kevin Macdonald, 2006). Hardly unique, Lloyd Young's experience in Enugu must be understood as part of a long history of misbegotten projects marked by the failure (or refusal) to actualize various fantasies of a truly Nigerian cinema. 
That Hollywood capital has nevertheless managed to benefit from these projects is evident, at the very least, from the global reception of The Mark of the Hawk, which turned a considerable profit over a period of several years and via a range of methods of distribution and techniques of publicity. Billed as having been "filmed in Nigeria by Hollywood camera crews," The Mark of the Hawk had its world premiere at New York's Paramount Theater on March 5, 1958. . $^{173 ~ " T h e r e ~ h a v e ~ b e e n ~}$ trimmer and more dramatic films on racism in modern Africa than 'The Mark of the Hawk," wrote Howard Thompson in the New York Times. "But one moviegoer has yet to hear a better suggestion on the subject: simple adherence to the teachings of Christ. It's about time." Thompson was especially pleased to see a film that did not appear to lionize "native terrorists" and that instead upheld "the calm influence of [the] American missionary." "The party responsible," he wrote, "is Lloyd Young, a man of whom we'd like to know more. As producer ... and originator of the story, Mr. Young has shaped-or tried to shape-a sermon in dramatic terms.... The trouble is simply that Africa speaks-incessantly." With this cheeky reference to Walter Futter's popular 1930 exploitation film Africa Speaks!, Thompson lamented Young's "talky" approach even as he expressed gratitude for the cinematic sermon. ${ }^{174}$

Writing in the New York Herald Tribune, William Zinsser upheld The Mark of the Hawk as an antidote to the Italian film The Last Paradise (Folco Quilici, 1955), of which Zinsser complained, "The producers took their camera to Polynesia, shot some beautiful color scenes of the islands, and then contrived some quaint legends for the story line.... The film fails to grasp the nature of life in the South Seas ... and even to the non-traveler it will seem artificial." By contrast, The Mark of the Hawk evinced, for Zinsser, a keen understanding of Nigeria, for "though it is fiction, it deals with issues that are real." "It is a neat coincidence that juxtaposes these two movies in the same week," he concluded. "One producer goes to Polynesia to make a documentary that turns out to be mostly fiction. Another goes to Africa to tell, under the guise of fiction, a story that is absolute fact." ${ }^{175}$ That Hollywood had somehow "captured" Nigeria was central to the film's reception in the United States. ${ }^{176}$

The Mark of the Hawk was especially popular at New York's Apollo Theater, where it played for one week in the spring of 1958, after finishing its first run at the Paramount. In December of the following year, the Apollo revived the film for a "pre-Christmas Film Festival," calling it "one of the finest pictures that Hollywood has made," and one whose "special impact on the Harlem motion picturegoing public" was deserving of further celebration. ${ }^{177}$ (The film's religious theme undoubtedly made it an ideal choice for this holiday engagement.) The previous year, the Apollo had helped publicize The Mark of the Hawk as "a remarkable motion picture achievement [that] was photographed almost entirely in Africa, with the full cooperation of the sovereign new nation of Nigeria." "Lloyd Young and Associates," the promotional copy continued, "brings Africa to the screen 
in all its lushly varied beauty, while telling a story of some people typical of the many whose daily lives are inexorably interwined [sic] in the tumultuous play and counterplay of its conflicting forces." 178 This widespread focus on the film's Nigerian shooting locations prompted Bosley Crowther to reassure readers of the New York Times, "[T] his does not mean that Hollywood is progressively closing up shop or even letting itself be superseded as the major area of film production in the world. It is still the recognized capital." 179 Other critics, directly contradicting Zinsser in their own reviews of The Mark of the Hawk, claimed that Nigeria was used inexpressively and almost arbitrarily. "It is impossible to quarrel with the good intentions behind 'Mark of the Hawk," argued journalist Win Fanning before complaining, "Precious little use is made of the African setting where many of the scenes were shot. And, for one long drawn-out sequence, the story is suddenly removed to China." In Fanning's view, the film “isn't interested so much in Africa as ... in racial tensions in general. This is laudable, of course, but it leads to scattering . . . shots so widely that few find the mark." 180

Religious leaders were far more likely to express enthusiasm, if only as a means of supporting the film's specifically Christian message and the continued production of religious films. After all, Lloyd Young \& Associates had received assistance from more than just Enugu: World Horizons Productions, a small, independent company that made films for the Presbyterian Church, also chipped in. ${ }^{181}$ When, in the fall of 1958, The Mark of the Hawk premiered in Washington, DC, it received "a unique salute from the city's clergy." Speaking through the Council of Churches, several religious leaders praised the film for its "believable, respectful portrait of a missionary." "[B] etween the extremes [of British colonialism and African radicalism] lies the patient, long road of the middle, represented by the missionary," wrote one Washington viewer. "Christianity, he quietly believes, is the only answer to this struggle erupting all over the world"-the only means of effectively convincing Africans in particular of their lack of the political capacity for immediate self-rule. ${ }^{182}$

As such commentaries indicate, American evangelicals were expected to work assiduously to forestall Black self-emancipation both at home and abroad. Dwight Eisenhower's personal pastor, the Reverend Edward Lee Roy Elson (who had baptized the US president in 1953 and would later be elected to the position of Chaplain of the United States Senate), singled out The Mark of the Hawk in a Sunday-morning sermon that Eisenhower attended. (Also present were the First Lady, Secretary of State John Foster Dulles, and Secretary of the Army Wilbur Brucker.) Elson "recommended the motion picture for all to see," and Eisenhower seconded the sentiment. ${ }^{183}$ That The Mark of the Hawk received the endorsement of the US president was a reflection, in part, of the Presbyterian Church's impassioned advocacy. But it also signaled the film's status as a useful weapon in the cultural Cold War.

The general audience appeared to share Ike's enthusiasm. Everyday filmgoers sent letters to various newspapers testifying to the salutary qualities of The Mark 
of the Hawk. "Average" viewer Mary G. Hundley told the Washington Post, "Permit me to express my opinion of the motion picture The Mark of the Hawk, now appearing at local theaters. A profoundly moving film with a message, it must certainly appeal to all people of goodwill." Hundley continued, "Here we have an eloquent plea for universal brotherhood and understanding, the inevitable solution of numerous human problems. The bond of Christian fellowship is a potent force for promoting world peace." Christian universalism could not obscure the specifically American dimensions of the film, however. Hundley's praise took a distinctly nationalist turn when she wrote, "Men of all creeds and races recognize American humanitarianism and our democratic ideals. Asian and African leaders are coming here in greater numbers than ever before. What impression of our Christian Nation will they carry home? This film can well answer. It is a challenge." 184

Eisenhower was not the only public figure to champion The Mark of the Hawk. In the spring of 1958, not long after his trip to Kwame Nkrumah's Ghana to observe that country's independence celebrations, Dr. Martin Luther King added his own praise. "'The Mark of the Hawk' is the most captivating and moving production that I have ever seen," King declared. "It states clearly, eloquently, and decisively the problem which the world confronts in the great social revolution that is taking place." King continued, "The theme of the film is dramatic, the message profound, and the acting superb. It has a deep and challenging message for both the oppressed and the oppressor. In a dynamic and electrifying way, this picture poses the theme of universal brotherhood. I recommend it to all people in the highest terms." 185 That King, "the great Negro leader," and Hundley, the Washington housewife, both used the term "universal brotherhood" suggests that the filmmakers had succeeded in conveying a coherent ideological message, one that, with its familiar Christian overtones, could be adopted and circulated with ease. Yet neither King nor Hundley mentioned Nigeria, and the country's absence suggests a different yet not-unrelated sort of success - that of a Hollywood production company in advancing the cause of American capitalism. Reporting on King's response to The Mark of the Hawk, Pittsburgh's Black newspaper noted, “Though the picture was filmed in Nigeria by a Hollywood independent, Lloyd Young and Associates, few can miss its implications for the USA. It can become one of the most powerful 'opinion shapers' of this decade." 186 The Mark of the Hawk had managed to effectively present American capitalism, with its secreted reliance on public subsidies and other forms of state support (both at home and abroad), in the language of human rights and socioeconomic justice-so effectively, in fact, that even King, who increasingly critiqued the capitalist system, raved about the film.

Other publications went so far as to present American capitalism as a weapon against "tribal terrorism," to quote a Los Angeles Times article on the film's production. ${ }^{187}$ " "The Mark of the Hawk' is a heavy yarn undoubtedly spun with great sincerity and a transcending nobility of spirit," wrote critic Geoffrey Warren, adding, "to promote the cause of Christianity, justice, racial equality and political and 
economic freedom all in one film is indeed an undertaking." ${ }^{88}$ Recognizing the film's intergenerational appeal, Parents' Magazine gave The Mark of the Hawk its Family Medal Award in the spring of $1958 .{ }^{189}$ The film was said to serve as a useful illustration of " $\mathrm{t}$ ] he middle way between [the] violent extremes of the submerged masses' worldwide modern revolutions." 190 The Mark of the Hawk, observed critic Kate Cameron, "petitions the natives to use patience in their efforts to bring about political reforms." 191

In 1960, the year of Nigeria's formal independence, The Mark of the Hawk was revived throughout the United States, beginning in New Jersey, where "A Visit to Africa, South of the Sahara" was the New Brunswick Presbyterian Church's latest "mission emphasis." In January, the church chose to screen The Mark of the Hawk, which it described as a "Hollywood film," as a means of ushering in the new year, with its special "African" mission. ${ }^{192}$ In April, a Methodist church in Los Angeles sponsored a Sunday-evening screening, inviting "several African students . . . to lead a discussion and to answer questions after the showing of the film." The church's goal was to help congregants "appreciate the complex problems of a country [sic] of the size of Africa." ${ }^{193}$ (It is not at all clear whether any Nigerians were actually present at the special screening.) And the film lived on. Between 1958 and 1995, The Mark of the Hawk was shown by at least two hundred American churches, and the film was regularly broadcast on American television until at least the turn of the twenty-first century. ${ }^{194}$

"An off-beat type of promotion is being employed to sell 'The Mark of the Hawk' by a series of individualized campaigns to various segments of the market," wrote the trade paper Film Bulletin in 1958. These campaigns were attracting "lobs of attention for the African-filmed Technicolor-Superscope" production, with such "diverse groups as Protestant churchgoers, teenagers, Negroes, Puerto Ricans, women's and educational organizations [being] exposed to beaucoup promotional activity." After The Mark of the Hawk completed its first run at the Paramount in Times Square, Universal, Lloyd Young \& Associates, the Board of Foreign Missions of the Presbyterian Church, the Methodist Church of America, and Film Productions International set up a series of "special screenings" in order to promote the film as a potential teaching tool for those interested in Protestantism, decolonization, anticommunism, and Africa. "Over one thousand clergymen and lay officials from the greater New York area viewed the picture at [such] special screening[s]," noted Film Bulletin. "'Mark of the Hawk' display cards, heralds, and special leaflets for distribution to church-sponsored women and youth groups were distributed to church officials. . ." "'195 A prominent fan of the film, Glenn Moore, then Secretary of the General Council of the Presbyterian Church, touted Nigeria as a source of "unusual entertainment" - a place of "discernment and beauty," the filmed record of which "should impress all who see it."196 "A film for all Christendom!" screamed ads for The Mark of the Hawk, two hundred thousand of which were distributed to pastors "for [their] Sunday Bulletins-Announcements-Sermons." ${ }^{197}$ Such 
hyperbolic appeals to the widest possible audience continued apace: "Calling all women!" read a later ad. "Calling all youth! A film for all young people who want to do something about today's world!"198

The profitability of The Mark of the Hawk cannot be gauged by conventional box-office figures alone. The usual metrics can go only so far in explaining the film's capacity to enrich its non-Nigerian participants. Universal's nontheatrical division was especially committed to the commercial circulation of The Mark of the Hawk beyond standard theatrical markets, and frequent benefit screenings were held-though not, of course, to the advantage of Enugu, on which Young and company had so strategically relied. The Mark of the Hawk continued to generate income for the United Presbyterian Church of North America well into the 1960s. ${ }^{199}$ During that decade, World Horizons Inc. distributed the film throughout Nigeria as part of the church's efforts to "develop urban ministries" in the country, but there is no evidence to suggest that these Nigerian screenings materially profited any local individuals or organizations, much less the Eastern Region government; the records of World Horizons indicate that all Nigerian returns were remitted to the United Presbyterian Church-a confirmation of the continued capacity of Nigerian state institutions to ensure the smooth repatriation of profits, which had attracted Young and other Hollywood representatives to Nigeria in the first place. ${ }^{200}$

Such smoothness did not go unnoticed by the Hollywood trade press. At the time, Hollywood firms faced major "remittance problems" in much of Africaincluding "all along the North African coast, in Algeria, Morocco, and Tunisia" but not in Nigeria. ${ }^{201}$ In that country, Hollywood films were easily imported under open general license, and dollars were abundantly available for remittances. In a wide-ranging report that accounted for the ongoing "distribution successes" of The Mark of the Hawk, the trade paper The Film Daily concluded, "There have been no serious problems reported ... regarding importation or exhibition of United States films in Nigeria." 202

The case of The Mark of the Hawk suggests an understudied late-colonial enactment of an enduring logic of neoliberalism, one that involved an emergent instrumentality (the Eastern Region government) and a newly established, "independent" instantiation of Hollywood's expansionist agenda (Lloyd Young \& Associates). As Michael Curtin argues, "concepts such as free flow and market forces are in fact meaningless without self-conscious state interventions to fashion a terrain for commercial operations." ${ }^{203}$ In summoning Young, the Eastern Region government telegraphed its own commitment to a certain perception of Hollywood expertise. It also anticipated later cross-cultural arrangements and exchanges. For instance, as the Nigerian Film Corporation was preparing to abandon its Victoria Island offices in the mid-1980s, the Eastman Kodak Company was called in to conduct comparative tests of the water in Lagos and Jos. The company's experts (duly compensated by the Nigerian state) found the water in the former city to be too 
hard for film processing, and Kodak-approved Jos became the headquarters of the NFC in $1987 .{ }^{204}$ Following Kodak's example, a group of carefully chosen Hollywood producers would visit Jos in 1991, at the request of the Nigerian government. There they were greeted by NFC general manager Brendan Shehu. "I am happy to welcome you to Jos, our movie capital," Shehu said. "This is not Hollywood-but, like Hollywood, it is the home of a film industry. Coming, as you do, from Hollywood's America, your visit to Jos should be the occasion for a dialogue and for proposals which should be of benefit to both our countries."205

Calling on Hollywood to "consider Jos," Shehu echoed the rhetoric with which the Eastern Region government had, over three decades earlier, appealed to Lloyd Young and other American investors, stressing scenic and climatic factors. "Nigeria, rich in culture and tourism, has much to offer to the [Hollywood] film industry," he said. "Your coming to Jos, a home widely known for its picturesque topography and accommodating weather, is hopefully the genesis of a healthy business relationship between us." Shehu's remarks suggest the continuity-the transhistorical stability-of appeals to foreign investment, particularly those issued from the ostensible periphery of the world economic order. Like his predecessors at the Cinema Corporation of Nigeria, Shehu touted the "investment prospects for Americans interested in Nigeria." "Film can help you see," he said, "what prospects there are for any investor coming to Nigeria or any filmmaker willing to have good locations to shoot his movie. Besides these, the Nigerian Film Corporation will be very willing to enter into agreement with your Chamber of Commerce or any representative agency for specific film production. This call for co-production is informed by the fact that you stand to gain from the yields as the exhibition of the films abroad will be part of the agreement." Speaking on behalf of the federal government, Shehu promised Hollywood producers in 1991 what had in fact come to pass for the makers of The Mark of the Hawk a few decades earlier.

Touting the possibility of "a joint working relationship" between Hollywood and the NFC, Shehu was quick to assure the former that its Nigerian operations would be unfettered-untaxed and altogether "lucrative," a "low-budget venture" whose "cheapness" could be guaranteed. ${ }^{206}$ Less plausible, of course, were Shehu's claims regarding the NFC's capacity to profit from such a venture. While he could convincingly promise Hollywood producers tax breaks and other forms of government assistance, Shehu could only feebly gesture toward indigenous dividends, addressing these in the broadest of terms: "The benefits to us should be tremendous," he said. "For the film business . . . can boost trade, diplomacy, culture, leisure, etc." His closing remarks, in which he touted Jos's eagerness "to be tapped and exploited," were telling. ${ }^{207}$ They were also-however unwittingly-accurate descriptions of what had transpired in the Eastern Region thirty-four years before.

Enugu may have been left out of these later developments in Hollywood internationalism, but, beginning in the 1980s, it served as the site of major advances in indigenous production that have culminated in the state's current status as a source 
of immensely popular, low-budget, Asaba-style Nollywood films-vernacular alternatives to the glossiness of the Lagos-based cosmopolitan productions that, in their own ways, evoke the capitalist pretensions of The Mark of the Hawk. Between the making of that film and Enugu's emergence as a fount of popular direct-to-video fare, the state served as a shooting location not only for the NTA's illustrious adaptation of Chinua Achebe's Things Fall Apart (1986) but also for Ola Balogun's industrial film Nigersteel (1975), about an Enugu-based steel company. ${ }^{208}$

Enugu's sporadic post-independence successes as a site of production of emphatically indigenous media should not, however, distract from Nigeria’s ongoing role as a source of tax breaks for American firms. The country has remained a significant player in the sort of global neoliberal development agenda emblematized by The Mark of the Hawk and later adopted by, among other Hollywood companies, Cinestar International. In the early 1960s, just a few years after Lloyd Young left Enugu for good, Cinestar promised to "provide [Nigerian] governmental units with an additional source of revenue through box-office taxes." At the same time, however, the company sought to preempt "the enactment or promulgation of any import regulation restriction, quota or ... import duty, tax, fee or other fiscal charge affecting" its operations in Nigeria. ${ }^{209}$

Power asymmetries have a tendency to perpetuate themselves. As David Harvey puts it, the "promised outcome of poverty reduction from freer trade, open markets and 'neo-liberal' strategies of globalization has not materialized"-a bleak lesson that the Eastern Region surely learned after collaborating with Lloyd Young \& Associates in the 1950 s. $^{210}$ The Mark of the Hawk was made ten years after the Nigerian premiere of Julian Roffman's unambiguously pro-capitalist A Greater Tomorrow, and it presaged some similar attempts to use the medium of film in order to promote American business norms (and individual American corporations) in Nigeria. After independence, the Socony Mobil Oil Company sponsored the awkwardly titled film Nigeria Economy Run (1960), a production of UniFilms, Inc., a firm based in New York, with a branch office and studio in Stamford, Connecticut. ${ }^{211}$ (The company also produced films and television commercials for Shell, Mobil's main rival in Nigeria.) ${ }^{212}$

Like the later A Village Is Waiting, Nigeria Economy Run depicts the Eastern Region in terms that echo those of The Mark of the Hawk. "A cathedral stands here in the East instead of a mosque," notes the American voice-over narrator with evident pride, as the film furnishes footage of white priests leading their Nigerian parishioners through a courtyard in the heart of Enugu. "Christianity"-the vanquisher not simply of atheistic totalitarianism but also of Islam - "shapes education and encourages industrial expansion in the Eastern Region. Large- and small-scale trade flourishes along the Niger and Benue." Shots of efficient typists characterize a sequence devoted to the streamlining of business operations in "modern" office settings. "Business and secretarial schools," the narrator notes, "help the people of the Eastern Region to rush to meet the business world more 
quickly than the Islamic North." Finally, the film turns to the topic of oil, which the narrator contextualizes in relation to Enugu's other affordances. "Oil was recently discovered in the East," he declares, adding, "Nigerians are developing their industry with their own research methods and their own hands. This Eastern Region of Nigeria is the only coal-producing area in all of West Africa. Eastern Nigerians utilize tribal and family groups to form trading firms."

However robust and American-inflected, such firms were no match for the neocolonial potency of the United States-a coercive power that has so often achieved expression (as with The Mark of the Hawk) in the financing, production, and distribution of motion pictures. Specific threats to Nigeria's cinematic independence tend to recur; histories of manipulation and exploitation have a way of repeating themselves. Not long after the making of Nigeria Economy Run, the Nigerian federal government, in an echo of Enugu's own brand of Hollywood outreach, commissioned an American production company to "collaborate" with it on the making of the nonfiction film The First Independence Day (1960). That company, Paragon Productions, based in Washington, DC, would go on to serve as sole distributor of the documentary, thus excluding the Nigerian state from a share of the profits from the global exhibition of a film that Lagos had conceived and co-financed. ${ }^{213}$

\section{LLOYD YOUNG'S LEGACY}

After leaving Nigeria for good in the late 1950s, Lloyd Young remained committed to the commercial potential of cinematic representations of decolonization, though he himself would be unable to help realize that potential. His filmmaking career petered out after The Mark of the Hawk. A planned Gandhi biopic was never made. In 1960, Young secured the exclusive film rights to Louis Fischer's The Life of Mahatma Gandhi (1950), overseeing negotiations between his production company and the Navajivan Trust, a semi-public corporation established by Gandhi himself (and chaired, at the time, by India's Minister of Finance). Mirroring other arrangements made on The Mark of the Hawk, Universal-International agreed to distribute the film, which Young planned to shoot on location in India. ${ }^{214}$ That year, as The Mark of the Hawk was being revived throughout Nigeria (including at the Roxy, the Emy, and other open-air cinemas in the Eastern Region), Young formed a partnership with the industrialist Fred de Wilde, with whom he planned to make a "musical fantasy" based on the life of Eartha Kitt. ${ }^{215}$ The Kitt film was never produced, and Young faded into obscurity, his sole cinematic success a measure, in part, of Enugu's firm commitment to Hollywood production.

While touring the United States in 1957, Young had proclaimed that, as of that year, there were approximately eighty theaters in Nigeria, and that the Cinema Corporation planned to build forty more in and around Enugu. ${ }^{216}$ Yet this could only be a classic case of "growth without development," since "foreign capital and 
extrinsic factors were the driving engine of [the planned] expansion." 217 By the end of 1957, the Cinema Corporation was obliged to lower its expectations, announcing that at least two "static cinemas" would be built in Onitsha and Enugu. By decade's end, none had been constructed. Dr. J.B.C. Okala, the chairman of the Cinema Corporation, called The Mark of the Hawk a "glorious edification of Africans who are fighting for freedom," yet by the time of the film's scheduled Nigerian premiere, in November 1957, no actual edifice had been built for the occasion, as promised. ${ }^{218}$

1961 saw the repeal of the Cinema Corporation of Nigeria Law, which in 1955 had established the eponymous body as a regional outfit-a producer, distributor, and exhibitor-distinct from the Eastern Region Film Unit, with its colonial parentage. As a result, the Cinema Corporation ceased to function in any form-even as a mere symbol of indigeneity and regional autonomy. Just as it was unceremoniously dismantled, however, Enugu announced plans to reserve a particular plot of land ("No. C/12") for a modern cinema equipped to show "major" imported films. A regional film bureau was killed, then, at the very moment that land was set aside for the construction of a big screen (to be adjacent to a swank hotel, no less) for the exhibition primarily of Hollywood products. ${ }^{219}$ The Eastern Region Film Unit fared better, at least in architectural terms, having completed the construction of its very own building, complete with editing suites, in $1963 .{ }^{220}$

Enugu continued to appeal to foreign film professionals, often employing them in place of local technicians. ${ }^{221}$ In 1962, not long after graduating from the University of Sydney, Australian director Bruce Beresford, who would go on to make such films as Breaker Morant (1980) and Driving Miss Daisy (1989), answered an ad that the Eastern Region government had placed for a film editor. Relocating to Enugu, Beresford worked in the region's film unit (a division of the Ministry of Information of Eastern Nigeria) until the outbreak of the Biafran Civil War prompted him to flee to London. ${ }^{22}$ He would return to Nigeria in 1990, however, shooting his adaptation of Joyce Cary's 1939 novel Mister Johnson on location in Kano. In a 2007 interview, Beresford recalled the squandering of Enugu's resources and the squelching of its cinematic potential by Western interlopers, though he stopped short of implicating himself in such mismanagement: "Enugu['s] government film unit . . . was a shambles. . . They never made any films there at all: it was run by a very strange Swiss man who seemed determined to do absolutely nothing." 223

The American evangelical spirit dramatized in The Mark of the Hawk was hardly impotent, however. The very missionary mechanism at the center of the film's narrative-the Christian purpose of the American cleric who journeys from East Asia to West Africa-had plenty of offscreen analogues in decolonizing Nigeria. In February 1960, just over a decade after he held his first tent revival in Los Angeles, the American evangelist Billy Graham brought his crusade to Enugu, where he received an enthusiastic welcome from some 35,000 Nigerians crowded into the city's massive Sports Stadium. ${ }^{224}$ (The impressive structure was an architectural victory - the site of a competing leisure industry - that stood in sharp, 
inviting contrast to the failure of the Cinema Corporation to construct any major movie theaters.) As Graham preached, memories of The Mark of the Hawk were activated. For here was an American who, like Lloyd Young before him, had come to Enugu to show Nigerians "the way." "It was while on location in Nigeria that the cast [of The Mark of the Hawk] became more aware of the history on which the movie is based-tensions [and] the missionary's role in easing them," claimed an American journalist on the occasion of Graham's crusade. ${ }^{225}$

If Nigeria could not be spared the sort of evangelism that Graham represented, then perhaps, some surmised, the country could at least be kept from drowning in a sea of imported Hollywood movies. Over two decades after the making of The Mark of the Hawk, the Nigerian filmmaker Eddie Ugbomah would go so far as to urge the federal government to ban the importation of all foreign films in order to enable the growth of a truly indigenous cinema. ${ }^{226}$ S.J. Timothy-Asobele would similarly call for protectionism: "The entry of foreign films into the country should," he said, "be restricted such that their continued importation does not stifle indigenous efforts. ... It is high time the government recognized the film industry as an economic product which is a component of the competition between Nigeria and the rest of the world." 227 In 1975, the Federal Commissioner of Information would claim that "foreign films, shown in the cinema houses, throughout the country, stretched the Nigerian economy and adulterated the nation's culture." 228 It was in response to this situation that Ola Balogun would volunteer as an advisor to the Nigerian government, a role through which he endeavored to promote the importance of state subsidies for local filmmakers rather than American interlopers like Young. ${ }^{229}$ As Balogun surely understood, The Mark of the Hawk does not even furnish an explicit acknowledgment of Nigerian national identity at the level of narrative. Exploiting the 1918 riots at Abeokuta, the 1929 uprisings in and around Calabar and Owerri (which George Padmore celebrated as "monster protest demonstrations against British imperialists and their agents"), ${ }^{230}$ the General Strike of 1945, and the Enugu colliery shooting of 1949, the film is nevertheless set in an unnamed African country, and the word "Nigeria" is never even uttered. Lacking a significant "degree of local reflection," The Mark of the Hawk served only to showcase Nigeria's "spectacular scenery," albeit in the absence of the sort of clear-cut narrative identification of the country that could, perhaps, have been counted on to promote tourism, as in typical subsidized productions. ${ }^{231}$

Ultimately, the making of The Mark of the Hawk was, in ideological terms, "subordinate to one fundamental cause: anticommunism"- a cause that cannot, of course, be disarticulated from the profit motive of Lloyd Young \& Associates, with its eagerness to cash in on what the State Department "envisioned [as] a golden opportunity to extend its Cold War outreach to Africa." 232 Bernard Blankenheimer, chief of the African Section of the Bureau of Foreign Commerce of the US Department of Commerce, touted this opportunity with great relish. ${ }^{233}$ But rather than aid Enugu, the film's production merely illustrated Pierre Jalée's claim 
that "in the very peak period of political decolonization imperialist exploitation not only persists but . . . becom[es] harsher." ${ }^{234}$ At the administrative level, the newly self-governing Eastern Region was willing to take a chance-particularly on an "upstart" like Young. Hollywood knew that. It brought to this public-private "partnership" a set of technical skills and a flair for promotion. Enugu brought a vision of indigeneity that, rather than coalescing into an operational local industry, ended up merely feeding its partner's global promotional faculties. "Africa" sells. If Hollywood had learned that lesson by the late 1950s, it would relearn it repeatedly in the decades that followed. Yet as the making of The Mark of the Hawk attests, the political-economic specificities of Nigeria were often more important-in practical as well as discursive terms - than continental generalities. 